\title{
EU Democracy Promotion in Eastern ENP Countries
}

Sergiu Buşcaneanu

Berlin Graduate School of Social Sciences

Humboldt University of Berlin

Luisenstr. 56, 10117 Berlin, Germany

Tel.: +491704927965

E-mail: serbuscaneanu@yahoo.com 


\section{Abstract}

The paper finds out that the increased incentive structures under the ENP and the more intense socialization dynamics in which Eastern ENP countries have been brought in since the launch of the ENP are not reflected into their regime patterns. However, on the long run (1991-2010) the EU democracy promotion in the region under consideration appears to be largely consistent. In addition, a content analysis of Progress Reports released by the European Commission on the implementation process of ENP Action Plans (ENPAPs) reveals that most Eastern partners have considered in their reform agendas the democracy-related objectives of these documents and that some have also sought to adopt international democratic instruments as provided for in the ENPAPs. Though the record is far from satisfactory on norm internalization, content analysis of Commission's Reports suggests that one should be cautious while totally sweeping away the EU's democratization role.

KEY WORDS: European Union, democracy promotion, European Neighbourhood Policy, Eastern ENP countries

\section{INTRODUCTION}

The European Union (EU) has an important role in ensuring that democracy gets supported and promoted. The EU had a tremendous success in achieving this objective in Central and East European Countries (CEECs). In the course of accession to the EU these countries have undergone a complex reform agenda in exchange for significant support and assistance preparing for membership. As the EU “big-bang” enlargement to the East was approaching, the EU has realised the need to reconsider and upgrade its relations with the new acquiring neighbourhood. The European Neighbourhood Policy (ENP) was thus born out in 2004 from an EU interest to forge in its immediate vicinity "a ring of friends” with whom to enjoy close and fruitful relationships. In the EU official discourse, the ENP aims at creating a wider area of stability, prosperity and security (European Commission 2004). The ENP's aim is framed in a "win-win” manner such that the more stable, better-off and secure the EU's neighbourhood would be, less risks for the EU will spillover. Yet, the philosophy of the EU hinges on the premise that democracy is a necessary ingredient for greater stability, prosperity and security. It is this credo which explains the EU emphasis on upholding and promoting democratic values and practices in the European neighbourhood. In what concerns the transposition of this credo on the ground, the EU builds on its successful experience in contributing to the consolidation of democracy in CEECs and relies on the same 
mechanisms of influence it did in the context of Eastern enlargement. It conditions delivering the incentives on offer within the ENP on compliance with international standards in the field of democracy, human rights and good governance. However, in contrast to accession countries, the membership perspective - the most valued EU reward - is not yet on the table for ENP countries.

To this end, this paper asks: To what extent the EU democracy promotion approach under the ENP has been effective and consistent? The cases with regard to which this question is considered are Armenia, Azerbaijan, Georgia, Moldova and Ukraine. Though the timeframe of interest is 2004-2010, for a greater analytical leverage the paper considers as well as the pre-ENP 1991-2003 period.

The paper proceeds in several moves. First, it outlines the main features of the EU democracy promotion discourse under the ENP. Second, it sets the analytical framework and formulates the hypothesis to be evaluated. Third, it seeks cues of conditionality and socialization in the ways the ENP is conceived and deployed. Forth, it resorts on the existing theoretical knowledge to derive relevant indicators, which are then analysed in a subsequent section. Finally, it considers the implementation of the democracy-related objectives of the European Neighbourhood Policy Action Plans (ENPAPs), as assessed by the European Commission in its regular Progress Reports, and the adoption of international democratic instruments promoted by the EU.

\section{Democracy Promotion Discourse UNDER THE ENP}

After a foot-dragging debut, the EU stance on democracy promotion started to get more substance in the aftermath of the Cold War. The failure of communism as an alternative modus operandi to democracy injected new momentum into the EU determinacy to encourage, support and promote democracy. EU democracy promotion efforts achieved their highest currency in Central and East European Countries (CEECs) given their aspiration to join the select EU club. The EU has developed a rewarding mechanism through which CEECs were offered substantial material benefits in return for compliance with accession criteria. The political criterion, which refers to the "stability of institutions guaranteeing democracy, the rule of law, human rights and respect for and protection of minorities”, had prominence among these criteria and was set as the basic condition for opening accession negotiations (European Council 1993). The same approach to democracy promotion was deployed for Western Balkans. The Stabilization and Association Process (SAP), conceived to prepare the Western Balkans countries for the EU membership, attaches also great significance to compliance with conditions related to human rights, democratic principles and good governance (European Commission 2001). 
Democracy promotion objectives have been expressed and extended in the EU treaty provisions, inserted into the multitude of bilateral and multilateral agreements concluded with third countries, and reiterated by the European Security Strategy (ESS). ${ }^{1}$

The EU democracy promotion discourse in the context of the ENP is an extension of that framed for CEECs, Western Balkans and in consonance with the EU determination to promote better democratic practices around the globe. Though it lacks the same amount of substance as in the case of CEECs and Western Balkans, given the absence of a membership perspective for ENP countries (ENPC), it is still more elaborate and nuanced in comparison with the democracy promotion discourse used in relations with other third countries. This steams from the high importance the EU attaches to its relations with neighbouring countries, as provided for in the ESS, ENP founding documents and treaty provisions. The ESS and ENP founding documents qualify neighbouring countries as the EU's essential partners, while the most recent treaty amendments introduced by the Treaty of Lisbon stipulates that "[t]he Union shall develop a special relationship with neighbouring countries, aiming to establish an area of prosperity and good neighbourliness, founded on the values of the Union and characterised by close and peaceful relations based on cooperation”. ${ }^{2}$

In generic terms, the ENP aims to develop a "ring of friends", to avoid drawing new dividing lines on the European continent and to share the benefits (or mitigate potential unfortunate consequences) of the EU enlargement. The EU vision is to see this ring of (well-governed) countries sharing the EU's fundamental values and objectives, engaged into an evolving close relationship, going beyond cooperation to involve significant economic and political integration (European Commission 2004). The way in which the EU sees realisation of this vision is by promotion of stability, prosperity and security within and beyond its new borders through greater political, security, economic and cultural cooperation. The ENP founding documents make clear the case that democracy, respect for human rights and the rule of law are essential prerequisites for increased stability, prosperity and security and the basis for a future privileged relationship between the EU and ENPC (European Commission 2003a, 2004). This credo cross-cuts the EU democracy promotion approach in the context of the

\footnotetext{
1 “Treaty on European Union”, Official Journal of the EU, C 191, 29.07.92; “Treaty on European Union” (consolidated text), Official Journal of the EU, C340, 10.11.97; “Treaty establishing the European Community” (consolidated text), Art. 181a, Official Journal of the EU, C325, 24.12.02; "Treaty of Lisbon amending the Treaty on European Union and the Treaty establishing the European Community”, Art. 10A, Official Journal of the EU, C306/50, 17.12.07; Council of the EU (2003), A Secure Europe in a Better World - European Security Strategy, http://www.consilium.europa.eu/uedocs/cmsUpload/78367.pdf.

2 "Treaty of Lisbon amending the Treaty on European Union and the Treaty establishing the European Community", Art. 7a, Official Journal of the EU, C306/50, 17.12.07.
} 
ENP and draws largely on the EU's successful experience in supporting the transformation process in accession countries. The ENP founding documents are replete with references to "shared values", as a basis for enhanced relations within the ENP, decoded in terms of "democracy, respect for human rights and the rule of law, as set out within the EU in the Charter of Fundamental Rights” (European Commission 2003a:4). The ENP seeks thus to reinforce the EU's contribution to the promotion and effective implementation of these "shared values", as essential elements of the relationship between EU and its neighbours (European Commission 2003a, 2004).

The ENP Action Plans (ENPAPs) signed between the EU and ENPC reiterate the mutual commitment for the promotion of stability, security and prosperity and maintain the paramount importance EU attaches to democracy-related values and practices. The ENPAPs concluded with Moldova, Ukraine (in February 2005) and with Armenia, Azerbaijan and Georgia (in November 2006) list among the main priorities of action: strengthening democratic institutions, the rule of law and the respect for human rights and fundamental freedoms. Yet, the first section of ENPAPs - "Political Dialogue and Reform” - outlines specific objectives and actions to be followed in these priority areas.

However, democracy-related matters are less under focus in the subsequent Commission's Communications aimed at proposing more attractive offers to the ENPC (European Commission 2006, 2007). Paradoxically, the Communication on strengthening the ENP, with the only exception of two references to human rights and another to the rule of law, keeps muted democracy-related concerns (European Commission 2006). ${ }^{3}$ Nevertheless, it does emphasize that some benefits to be put on offer for ENPC (e.g. additional funding from the Governance Facility) would be considered in the light of progress in implementing the governance aspects of the ENPAPs, particularly those related to human rights, democracy and the rule of law (European Commission 2006, 2007). ${ }^{4}$ The Communication entitled “A Strong ENP” brings again in light the democracyrelated matters and reiterates the importance of an EU external policy which is effective in promoting transformation and reform in its neighbourhood (European Commission 2007). It reiterates EU’s commitment to promote stability through "the sustained promotion of democracy, human rights and the rule of law throughout

\footnotetext{
${ }^{3}$ Ironically, the 2006 Communication on Strengthening the ENP mentions as one of the ENP's strengths the fact that given the single and overarching framework of ENP it became more difficult focusing exclusively on economic issues without considerations of "uncomfortable governance or human rights issues”.

${ }^{4}$ A clarification as to which issues "governance aspects” are related with was made by the “A Strong ENP” Communication (European Commission 2007:10). They seem to be better captured by the “democratic governance” concept which is about the legitimacy of how "the rules of the political game are managed” and not about the efficiency of this process which relates to the broader "good governance” concept (cf. Freyburg 2009).
} 
the neighbourhood” (European Commission 2007:7). It also stresses that the new offers foreseen for the ENPC (e.g. mobility partnerships) should be in line with the EU's external and internal policy goals and help projecting EU values.

The Eastern Partnership (EaP), launched to counterbalance a prominent European interest for the Southern dimension of the ENP, keeps high on the agenda the EU interest to help its partners build vigorous and stable democratic institutions. The Joint Declaration of the Prague EaP Summit underscores that EaP will be based on commitments to democracy, the rule of law and the respect for human rights and fundamental freedoms (Council of the EU 2009). Yet, at the operational level “democracy, good governance and stability” was made the first thematic platform of the multilateral dimension of EaP (European Commission 2008, Council of the EU 2009).

In short, the EU has properly entered the democracy promotion business only when the Cold War was over. Since the beginning of 1990' the EU democracy promotion has evolved from a discrete aspect of the EU development policy to a fundamental objective of the EU foreign policy. At the same time, the EU effort aiming at this objective have gradually spanned across various geographical regions, but it achieved the highest complexity and effectiveness in the case of accession countries from Central and Eastern Europe. Though short of the membership perspective, the EU democracy promotion approach in the context of the ENP builds on its successful experience of driving domestic change in accession countries.

\section{ANALYTICAL FRAMEWORK \& HYPOTHESIS}

The literature on the EU democratizing impact explores two main causal models: conditionality and socialization. Conditionality model is a rational choice bargaining model. It assumes that actors are rational bargaining players motivated to maximize their own material and power interests. In this model the outcome of the strategic exchange among the actors is said to be conditional on their relative bargaining power, i.e. the higher the power asymmetry between an external agency and a target state, the higher the leverage of the former on the latter. Rational choice account assigns to this model the "logic of consequentiality" and portrays conditionality as relevant for international norm promotion. Its effectiveness depends on the size and credibility of rewards and sanctions provided by the normative agents, and on the domestic veto points and costs of adaptation. According to this logic, transposed to the EU context, the larger the size and credibility of EU rewards and sanctions, the greater the chance that they will change the cost-benefit calculations of the target 
country. Hence, the cost-benefit balance is contingent on the size and credibility of rewards, on the one hand, and the size of domestic adoption costs, on the other. Under this model of action the EU does not intervene coercively to change the cost-benefit assessment and subsequent behaviour of the target government, but rather upsets the "domestic equilibrium" (status quo) by introducing incentives for reform into the game (Schimmelfennig 2005). On the extent to which a third country complies with the EU condition to internalize certain EU (democratic) norms depends whether it receives or not the reward. However, any action towards compliance depends further on the domestic power equilibrium and on whether the benefits of the rewards exceed the domestic costs of transformation.

In contrast, socialization, defined as a process of inducing actors into the norms and rules of a given community, is a constructivist theoretical model (Checkel 2005, Zürn and Checkel 2005). It goes beyond the material bargaining perspective and assumes the "logic of appropriateness" (March and Olsen 2004). According to this logic, actors' actions are driven by rules of appropriate or exemplary behaviour, i.e. they do what they see as appropriate for themselves or seek to do "the right thing” (Börzel and Risse 2009:10). Thus, they follow those courses of action which are seen as natural, rightful and legitimate. Adopted to the EU context, which is defined by a particular collective identity, and common values and norms, it follows from this perspective that whether a non-member state adopts the community's rules depends on the degree to which it regards them as appropriate to its own identity (Schimmelfennig 2005:7). The ways in which socialization operates it is explained in sociological institutionalist literature by the means of three causal mechanisms: (a) role playing, (b) normative suasion and (c) social influence (cf. Checkel 2005). By role playing, known also as “imitation” or “emulation”, socializees imitate the behaviour of socializers and adopt international norms that serve as templates and scripts for the roles the former are supposed to play in the international community. Under this mechanism internalization of international norms by socializees is said to be unreflective (Checkel 2005:811, Schimmelfennig 2005:7). The second mechanism of normative suasion, called also "argumentation” or “persuasion”, suggests that international norms are normative claims justified persuasively by socializers in international discourses. Persuaded by the legitimacy and validity of international norms, socializees may choose to adopt them. Hence, social learning it is said to imply in this case a reflective process of normative internalization (Checkel 2005:812). Finally, the variation in the adoption of international norms is explained by reference to social influence, which is based on the use of social rewards (image, prestige) and punishments (shaming, isolation). 
At a lower explanatory level the literature identifies several scope conditions for the above mechanisms of social learning: duration and intensity (of contact between socializers and socializees), previous experiences (of target states in international policymaking settings), novelty (of the environment in which a given socializee finds itself), legitimacy (of international norms), identity (of a target state relative to that of a larger community of states), authority (of agency), and resonance (of international norms with domestic values, norms, practices and discourses) (cf. Checkel 2005).

The literature on the EU democratizing impact converges to a consensus that the role of political conditionality was pivotal in bringing about domestic change in CEECs (Kubicek 2003, Kelley 2004, Schimmelfennig 2005, Schimmelfennig and Scholtz 2010, Vachudova 2006, Mungiu-Pippidi 2005). The research findings confirm that the effect of political conditionality on domestic arenas in CEECs has increased the more the size and credibility of rewards EU has put on offer in turn for reforms have also increased. Particularly high the effect of political conditionality was when the EU membership perspective, the most valued incentive, became also highly credible in the eyes of accession countries and when the domestic power costs of adopting democratic norms were low. Schimmelfennig (2007) underscores that these two conditions have been individually necessary and jointly sufficient for effective democracy promotion in CEECs. Though this literature does not claim that the EU accession conditionality is more important than domestic conditions of democratization, it shows that in many cases the EU external rewards helped domestic actors to forge consensus over their reform agendas and to overcome the domestic costs of transformation. Nonetheless, the above findings do not annul the role of socialization which worked well when the domestic opposition to the EU transformative effort was low (Kelley 2004).

To this end, the EU-related influence can be hypothesised in the following way: The level of democracy is contingent on the effectiveness of EU democracy promotion, which increases with the size and credibility of the EU's conditional incentives, and with the intensity of socialisation mechanisms. Before moving on to operationalization of this hypothesis, one should have a short look at the manner in which conditionality and socialization get expressed in the framing of ENP.

\section{CONDITIONALITY AND SOCIALIZATION UNDER THE ENP}

As provided for in the “wider Europe” Communication, conditionality gets expressed in the principle of differentiation, which means linking the benefits on offer for neighbouring countries to their progress made in 
political and economic reform (European Commission 2003a:9). At the same time, the ENP Strategy Paper proposes that differentiation should be based on a clear commitment to "shared values" (European Commission 2004:8). The incentives are proposed to be introduced gradually and in tandem with achieved progress (European Commission 2003a:16). In case of significant performance in attaining agreed priorities, the ENP Strategy Paper sets out for the incentives to be reviewed so that further steps along the path of greater sectoral integration are undertaken (European Commission 2004:9). To make it even more demanding the ENP Strategy Paper maintains that the actual delivery of benefits requires effective implementation of the agreed measures (European Commission 2004:14). With respect to benefits, the EU specifies that in return for progress demonstrating "shared values and effective implementation of political [...] reforms, including in aligning legislation with the acquis" neighbouring countries "should be offered the prospect of a stake in the EU's Internal Market” and of further integration and liberalization to promote the free movement of persons, goods, services and capital (European Commission 2003a:10). In addition, the Commission identifies “shared values”, democratic institutions and respect for human rights as foundations (read: conditions) for, inter alia, deeper political relations, enhanced cooperation on governance, justice, CFSP, ESDP, and environment improvement (European Commission 2003a:12). The differentiation principle resurfaces in the Commission's documents through the proposal that the EU should accompany progress made in reforms with enhanced assistance (European Commission 2003a:14). To this, the Strategy Paper adds that whenever financial assistance is negotiated with the ENP partner countries the conditionality element should draw on the economic priorities and measures of the ENPAPs, ensuring that assistance is an additional incentive to pursue political and economic reform (European Commission 2004:25).

The ENPAPs, in line with the ENP Strategy Paper, inform that the level of ambition of the EU's relationships with each partner country will depend on its degree of commitment to "common values" as well as its capacity to implement jointly agreed priorities (cf. ENPAPs, European Commission 2004). The Action Plans underline also that the pace of progress of the relationship will acknowledge the efforts and achievements of target countries in meeting those commitments. With regard to the new contractual links to follow after the PCAs, the ENPAPs stress that in light of the fulfilment of Action Plans' objectives and of the overall evolution of bilateral relations consideration will be given to the possibility of new contractual relationships. This is a reiteration of the ENP Strategy Paper which proposes that new contractual relationships could take the form of European Neighbourhood Agreements (European Commission 2004). In the singular case of Azerbaijan, among the EU Eastern neighbours, the corresponding ENPAP indicates that any breach to "common values, [...] 
international and European norms and principles” by either party will result in the immediate suspension of its implementation.

The Communication on "Strengthening the ENP" emphasises that the principle of differentiation should remain at the heart of the policy and that the EU should provide even more support and incentives to those neighbouring countries that are willing to reform and achieve tangible progress (European Commission 2006). ${ }^{5}$ The new foreseen Governance Facility was conceived explicitly to reward those ENPC making the most progress in implementing the governance aspects of the ENPAPs and to help them strengthening their domestic constituencies for reform (European Commission 2005, 2006:12). The following Communication “A Strong ENP” makes clear that within the broadly-defined governance aspects those related to human rights, democracy, and the rule of law are of central concern for the EU (European Commission 2007). The Communication reiterates also the "more for more” logic of the ENP.

The EaP was conceived to boost the EU offer for its Eastern neighbours. It reinforces the principles of conditionality and differentiation, by proposing a more substantial offer for neighbours, connected to the degree to which they transpose commitments to democratic values in national practices and policy implementation (European Commission 2008, Council of the EU 2009). Commission Communication introducing the EaP emphasizes that "a sufficient level of progress in terms of democracy" will be a precondition for starting negotiations on the new Association Agreements and for deepening relations thereafter (European Commission 2008). ${ }^{6}$

What is also worth mentioning is that the ENP is used to reinforce the democratizing leverage of other international organisations, such as UN, CoE and OSCE (cf. Casier 2009). The ENP documents, but especially the ENPAPs are replete with references to democracy-related standards defined under the aegis of one of these organisations (European Commission 2003a:16, cf. ENPAPs). Nevertheless, conditionality under the ENP sets less pressure for adaptation than that for accession countries and gets close to what it has been called "negotiated conditionality” or “conditionality-lite” (Nikolov 2007, Sasse 2008).

\footnotetext{
${ }^{5}$ The Communication proposes new incentives such as: a "deep and comprehensive FTA", common visa application centres, Governance Facility, Neighbourhood Investment Facility. The proposals set out in this Communication are said to represent a robust offer to the ENPC (European Commission 2006:14).

${ }^{6}$ The Council of the EU has apparently relaxed later this condition by allowing for AAs between the EU and "those partner countries who are willing and able to comply with the resulting commitments” (Council of the EU 2009). As a result, by July 2010 all Eastern neighbours of the EU, except Belarus, have launched negotiations on the AAs.
} 
Cues that the EU relies on socialization to induce norm adoption and internalization are omnipresent. ${ }^{7}$ The ENP itself as an overarching policy framework was conceived in the first instance to socialize selected third countries into the European norms, standards and practices across a large number of policy fields. Yet, the way EU understands the implementation of the ENP, relying on partnership, active participation and cooperation of its partners, denotes a predilection for a rather network structure of relations than for a hierarchical one (cf. Youngs 2009). The dominant mechanisms of socialization the EU makes use of within the ENP are normative suasion and social influence. The EU had to persuade its partners while negotiating the ENPAPs on the necessity to consider objectives and actions whose fulfilment will bring them closer to international standards. Arguing in favour of particular domestic reforms is part of the communication tool-box the EU uses in relation with ENPC during the regular meetings of cooperation councils and (sub)committees established by PCAs or AAs, highlevel summits, thematic dialogues, expert-level meetings, etc. At the same time, the EU seeks to influence its neighbours to conform to internationally-accepted norms via assessing their performance by the means of regular Progress Reports, praising the best performers and "shaming” the less successful partners. The EU expects also that its partners commit themselves to the reform agenda as defined by the ENPAPs. To increase the likelihood for partners to engage in role playing the EU has sought to give them a say with regard to the design and realisation of the ENP (e.g. identifying the scope and substance of ENPAPs), ensuring thus national ownership of the policy.

In a nutshell, the EU relies within the ENP on the same mechanisms of influence it did in the context of enlargement to induce norm adoption and internalisation. Conditionality and socialization reappear in the ENP founding documents and get further expressions in the realization of ENP on the ground. In terms of the research design, this requires operationalization of their causal role as being hypothesized above. The following section has this concern in the focus.

\section{DESIGN}

\subsection{RESEARCH QUESTION, CASES, TIMEFRAME}

\footnotetext{
${ }^{7}$ There is an abundance of terms signalling reliance on socialization in the documents setting up the ENP: enhanced political dialogue and cooperation; economic integration; close societal, cultural links; legislative and regulatory approximation; participation in EU’s programmes; technical assistance (e.g. TAIEX, TWINNING); academic exchanges (e.g. EMECW); mobility partnerships; etc.
} 
The research question to be answered by this paper is: To what extent the EU democracy promotion approach under the ENP has been effective and consistent? Democracy promotion is understood by the EU as a process through which different instruments and forms of assistance are used to advocate, support or bring pressure to secure policy changes aiming at democratic development (Council of the EU 2006). Effectiveness and consistency with which the EU achieves this goal in the context of the ENP are to be considered. By the former it is meant the EU capacity to induce its neighbours to adopt and implement democratic norms. The latter relates to the EU action in line with one of the main principles on which the ENP builds: differentiation. The EU has pledged to use this principle so that the more conforming ENPC get in turn higher rewards and further incentives respectively: “more for more” principle.

Cases for which the above specified research question is addressed are all Eastern neighbours of the EU involved in the ENP: Armenia, Azerbaijan, Georgia, Moldova and Ukraine. ${ }^{8}$ They are also participants in the Eastern Partnership (EaP), launched in May 2009 as the Eastern dimension of the ENP. The timeframe to be covered is: 1991-2010, with the following three sub-periods: 1991-1998, 1999-2003, 2004-2010. ${ }^{9}$ The research timeframe includes a pre-ENP period in order to identify ex-ante and ex-post differences in the EU approach to democracy promotion.

\subsection{VARIABLES AND INDICATORS}

As implied by the research hypothesis (§2), the outcome variable of interest is democracy, while the explanatory variable is EU democracy promotion. To be sure, the paper falls short of any attempt to measure democracy per se. It rather assesses the extent to which EU democracy promotion has been reflected into the regime patterns, as measured by: (a) Political Rights (PRs) ratings of Freedom House (FH) in the Freedom in the World survey $^{10}$ and (b) Polity IV Project. ${ }^{11}$

\footnotetext{
${ }^{8}$ The extension of the ENP to Southern Caucasus was proposed by the Commission's ENP Strategy Paper in 2004. Belarus, though invited, did not join the ENP. EU-Belarus relations stalled in 1996-1997 as a consequence of setbacks in the development of democracy and human rights, in particular the replacement in 1995 of the elected parliament with a national assembly nominated by the President in violation of the 1994 constitution.

${ }^{9} 1991$ stands as the beginning of a new period given the dissolution of the Soviet Union; 1999 is the year when the official formalization of contractual relations between the EU and target countries was finalised (as of 1999 all Partnership and Cooperation Agreements between the EU and concerned countries entered into force); 2004 is the year when the ENP was launched.

${ }^{10}$ Freedom House, Freedom in the World, http://www.freedomhouse.org.
} 
Given the fact that the explanatory variable reflects a broad conceptual category, this "unobservable latent variable” is related to "observable indicators”. In doing that I follow the reasoning of psychometric theory which suggests that an index that is composed of multiple indicators of the same underling concept is likely to be more accurate and more reliable than any single indicator (cf. Ragin 2008). Yet, given the way in which EU frames the ENP two intervening variables need to be specified: conditionality and socialization.

Conditionality is accounted for with the following indicators: bilateral agreement; EU assistance per capita; commercial and visa regimes. On the other hand, socialization is accounted for with: EU programs; TAIEX and TWINNING activities; European regional organisations, trade with EU, and proximity to the EU.

Schimmelfennig and Scholz (2008, 2010) argue that different types of bilateral agreements regulating the relationship between the EU and third countries reflect different levels of credibility these countries attach to the incentives EU puts on offer through such agreements. Following this line of argument, it is assumed that the credibility of incentives offered by the EU to Armenia, Azerbaijan, Georgia, Moldova and Ukraine through the PCAs was higher than the credibility of benefits offered before PCAs entered into force. At the same time, this credibility is lower than that of rewards foreseen by the more recent ENPAPs. Nevertheless, the credibility of benefits offered through the ENPAPs fall short of that carried out by European Agreements which provided a membership perspective to the CEECs. As to the size of rewards, it varies depending on the amount of $E U$ assistance per capita. The larger the EU assistance, the higher the value of the perceived reward. The same reasoning can be used with regard to the type of commercial (GSP, GSP+, ATP) and visa regimes (not-free, facilitated) being in place between the EU and its neighbours. The more advanced these regimes, the higher the size of the perceived reward.

If accounting for the conditionality dimension of the EU democracy promotion approach is more or less an easy-going exercise, identifying precise indicators for socialization dimension is a more daunting task. Such an operationalization is hindered by the fact that constructivist literature on socialization does not single out clear-cut indicators which can be used universally across cases. The problem of identifying such indicators steams from a serious difficulty of deriving indicators for such fine-grained causal mechanisms the constructivist literature operate with: role playing, argumentation and social influence. Indeed, how could one find out with great confidence that a target country has adopted a particular norm through one of these models? However, the constructivist accounts do make clear that the intensity of interaction and duration of contact between socializers

11 Marshall, M.G. and Jaggers, K., Polity IV Project: Political Regime Characteristics and Transitions, 1800-2010, http://www.systemicpeace.org/polity/polity4.htm. 
and socializees are relevant conditions explaining the extent of socialization (Zürn and Checkel 2005). Hence, they can be seen as a function of: instances of participation of ENPC in EU programs and in TAIEX and TWINNING activities; duration of presence and membership instances of concerned countries in European regional organisations. By the latter, it is meant those European organizations where the EU member states represent a significant share (e.g. CoE, OSCE).

As the effect of socialization depends on the intensity of interaction between socializers and socializees, trade with EU and proximity to the EU are viewed as appropriate proxies in this regard. The first proxy accounts for the share of trade with the EU in the total trade of ENPC and provides hence an indication of the level of economic interaction between the EU and its neighbours. Yet, O’Loughlin et al. (1998) underscore that geographical proximity increases the number of interactions that can promote democracy or authoritarianism. That is, the closer countries are to each other, the greater the number of possible linkages through which democracy or autocracy can spread. To this end, insofar as proximity is concerned, one could distinguish direct and non-direct land neighbours of the EU. Though any measure of socialization can never be exact, the selected corresponding indicators seek to approximate its value. ${ }^{12}$

\subsection{ConCEPTUAL MODEL}

The conceptual model in Figure 1 assembles a formal representation of the hypothesised relationship between variables.

\section{[Figure 1 about here]}

The developed analytical model allows for different levels of abstraction to be transcended, to discern the hypothesis built into the concept structure, to scrutinize the relationships among constitutive elements of the structure and to translate the model into a measurement strategy (Goertz 2005).

\section{EU DEMocracy PRomotion}

\subsection{CONDITIONALITY}

\footnotetext{
${ }^{12}$ For additional information on indicators see Appendix 2.
} 


\section{Bilateral Agreements}

For several years after the implosion of the Soviet Union, there was no formal relationship between the Newly Independent States (NIS), except Baltic States, and the EU. The first important move towards formalization of their relationships was the signature in the mid of 1990' of the Partnership and Cooperation Agreements (PCAs). These documents have been signed with all former soviet republics, except Baltic States and Tajikistan, replacing the Agreement between the EEC, EURATOM and the USSR on trade and economic and commercial co-operation concluded in December 1989. Given the cumbersome procedure of ratification by national parliaments and by the EU Member States, the PCAs with Moldova and Ukraine entered into force in 1998, whereas those with Armenia, Azerbaijan and Georgia in 1999. Since then they set the framework for bilateral rapports in several important areas such as: political dialogue, trade, business and investment, payments and capital, competition, economic, financial, legislative, cultural cooperation, etc. They proclaim respect for democracy, principles of international law, and human rights as an essential element of the partnership, constitute the legal resort for the EU to support partner countries in consolidating democracy and ask from the latter to observe the principles of democracy, to respect and promote human rights. The PCAs lay also the formal basis regulating the provision of certain benefits to partner countries. Through the PCAs the Parties agreed to accord one another the most-favoured-nation treatment with regard to trade in goods and to consider the establishment of a free trade area (FTA). The PCAs also set, in general terms, an agenda for legislative and regulatory approximation. However, they do not provide for a fixed timetable in what concerns FTA and regulatory approximation. Equally, it was established that within the TACIS framework the EU will provide technical assistance in the form of grants to facilitate economic transformation. The credibility of providing or withholding these incentives was hinged only on a general provision which reads that Parties shall take any general or specific measures required to fulfil their obligations under these agreements. ${ }^{13}$ The lack of strong and explicit legal obligations addressed equally to both Parties, but also the overall (weak) development of bilateral relations at that time made the EU promises (and threats) sound little credible on the part of partner countries.

The ENPAPs have led to an upgrade of bilateral relations and brought an added-value compared to PCAs in terms of incentives proposed to be offered to the EU's neighbours. The EU's determinacy to help forge

\footnotetext{
${ }^{13}$ Partnership and Cooperation Agreements (PCAs): Russia, Eastern Europe, the Southern Caucasus and Central Asia, http://europa.eu/ legislation_summaries/external_relations/relations_with_third_countries/eastern_europe_and_central_asia/r17002_en.htm.
} 
the well-branded "ring of friends" who would share the benefits of an enhanced relation "going beyond cooperation to involve a significant measure of economic and political integration”, but also the unbeaten proof of how supportive the EU can be for its partners (read: accession countries) increased the credibility of its promises made for the ENPC. Though increased without doubt, this credibility still falls short of that carried out by Association Agreements concluded between the EU and CEECs.

\section{EU Assistance}

Along with providing support to build state institutions, undertake political and market economy reforms, the EC committed itself to offer appropriate technical and financial assistance to NIS. Since 1992 the EC assistance was channelled through the TACIS programmes, including its national, regional and cross-border components, under several thematic budget lines such as the Food Security Programme (FSP), the European Initiative for Democracy and Human Rights (EIDHR), macro-financial assistance, humanitarian assistance, etc.

With the entry into force of the PCAs, a more targeted framework for channelling the EU assistance to NIS was established. An evaluation of the TACIS programme made for the Commission in 2006 came to the conclusion that TACIS interventions were overall highly relevant and responded to the needs identified (Short $e t$ al. 2006). However, certain drawbacks of the TACIS assistance programme were noted. First, TACIS programme, particularly in the early years, was mainly governed by a “top-down” approach. According to evaluation, this was partly a consequence of the need for institution-building and partly due to an insufficient sense of ownership on part of the national authorities. Second, National Indicative Programmes (NIPs) tended to be too detailed which restricted adaptability at project identification level to respond flexibly to evolving needs. Third, TACIS programme was characterised by a large number of "stand-alone” technical assistance projects, particularly in the area of institutional and administrative reform. In this respect, these actions often achieved good results at project level, but had less impact at sector and national policy level partly due to a lack of continuity and coherent long-term sector planning. Equally, the projects were not always "affiliated to concrete initiatives funded by the government” which had a negative impact on project sustainability (Short et al. 2006). On the contrary, evaluators noted that the FSP had a bigger impact at policy and sectoral level due to higher national ownership leading to stronger commitment to implement reform proposals and policies.

Before the official launch of the ENP in 2004, the Commission proposed in June 2003 a two-step approach concerning the creation of a "new Neighbourhood Instrument”. In line with this proposal, for the initial 
phase 2004-2006, Neighbourhood Programmes based on improved coordination among existing instruments INTERREG, PHARE, TACIS, CARDS and MEDA - have been introduced within the existing legislative and financial framework. The second phase started in 2007 with the launch of a new financial instrument, European Neighbourhood and Partnership Instrument (ENPI), aimed at addressing the "common challenges” identified in the “wider Europe” Communication (European Commission 2003b).

Taking into account the shortcomings of assistance under TACIS, the EU's assistance under the ENPI was conceived to focus from 2007 onward on a limited number of priority areas rather than on specific technical assistance projects. Strengthening of democratic structures and good governance or (in a different formulation) support for democratic development (including the rule of law) and (good) governance is the first priority area common to all Eastern EU neighbours. The NIPs for the 2007-2010 period set to be spent on the first priority area amounts ranging from 25 to $35 \%$ out of the total funds. ${ }^{14}$

With the launch of the ENP the EU has committed to increase significantly the funds made available for ENPC (European Commission 2004:9). Indeed, the total allocations for the region covered by the ENP have increased with $32 \%$ in real terms up to 11,18 billion $€$ for the $2007-2013$ financial framework. ${ }^{15}$ However, the picture appears mixed when considering the EU assistance per capita instead of total financial allocations for the ENPC. Two observations are here in order. First, contrary to what one could expect, EU assistance per capita diminished in the period 1999-2003, i.e. after the entry into force of PCAs. Second, since the launch of the ENP in 2004, Georgia and Moldova are the only countries in the region where the EU assistance per capita has been indeed increased. In the case of Armenia, Azerbaijan and Ukraine, as shown in the Figure 2 below, the contrary can be observed.

\section{[Figure 2 about here]}

\footnotetext{
${ }^{14}$ Armenia: 29,52 mil $€$ or $30 \%$ out of 98,4 mil $€$; Azerbaijan: 30 mil $€$ or $32,6 \%$ out of 92 mil $€$; Georgia: 31,5 mil $€$ or $26 \%$ out of 120,4 mil $€$; Moldova: between 52,4-73,4 mil $€$ or between $25-35 \%$ out of 209,7 mil $€$; and Ukraine: 148,2 mil $€$ or $30 \%$ out of 494 mil $€$ (European Commission 2006c-g).

${ }^{15}$ EU (2006), "Regulation (EC) No 1638/2006 of the European Parliament and the Council of 24 October 2006 laying down general provisions establishing a European Neighbourhood and Partnership Instrument”, Official Journal of the EU, L310/1, 09.11.06; European Commission (2011), European Neighbourhood Policy: Funding, Internet web site for the European Commission, accessed 30 ${ }^{\text {th }}$ April 2011, http://ec.europa.eu/world/enp/funding_en.htm.
} 
If one considers the committed volume (Figure 3), the EU assistance per capita under the ENP would represent indeed an increase, with the only exception of Azerbaijan. However, the difference between the disbursed and committed amounts of assistance under the ENP is negative in the case of all considered countries. $^{16}$

\section{[Figure 3 about here]}

When it comes to consistency, the picture is again mixed. It does not seem that the EU takes entirely into account performance in the area of democracy, human rights and the rule of law when deciding country allocations. The EU appears, as Figure 4 shows, to reward objectively under the ENP only Armenia and Georgia.

\section{[Figure 4 about here]}

The downward and upward trends in EU assistance per capita in these two countries in the 2004-2010 period correspond to the overall regime patterns as assessed annually by FH and Polity IV Project (Figure 4a,c). In the case of Azerbaijan (Figure 4b), though both FH and Polity IV maintain the same ratings for the 2004-2010 period, but also for some years before the launch of the ENP, the EU assistance per capita decreased significantly. For Moldova the situation is different: though it seemed to backslide in terms of democracy and human liberties in the 2004-2010 period, the EU assistance per capita increased (Figure 4d). Finally, the most “mistreated” partner in the Eastern neighbourhood appears to be Ukraine. Though both FH and Polity raise their ratings for Ukraine during the 2004-2010 period, the EU assistance per capita remained largely at the level of that offered in the preceding 1999-2003 period (Figure 4e). The "more for more" or, via logical extension, the "less for less” principle was applied consistently only in the case of Armenia and Georgia. The former is an example of "less for less", while the latter is an example of "more for more". This means that in terms of the disbursed financial assistance to the Eastern neighbours the EU has been only partly consistent since the beginning of ENP. The same can be said about the EU assistance in the entire 1991-2010 period, as shown in the Figure 5 below.

\footnotetext{
${ }^{16}$ For the 2004-2010 period, the mean differences between disbursed and committed values of EU assistance per capita is, as follows: -3.95 euro for Armenia, -0.59 euro for Azerbaijan, -3.14 euro for Georgia, -0.42 euro for Moldova, and -0.94 euro for Ukraine. One should mention that ENPC also get funding under two additional ENPI budget lines: regional (East/South) and cross-border cooperation. This added to the disbursed bilateral aid might indeed increase the EU assistance per capita provided to all Eastern neighbours since 2004.
} 


\section{[Figure 5 about here]}

Without being the regional leader in terms of democratic liberties in the 1991-2010 period, Georgia has received the highest amount of assistance per capita from the EU, while Ukraine being not less democratic than Georgia received only slightly more assistance compared to the underperformer Azerbaijan.

\section{Commercial Regime}

The EU has committed to offer to all neighbouring countries "the prospect of a stake in the EU's Internal Market” (European Commission 2003a). The "stake” means enhanced preferential trade relations, and more open trade so that ENPC get better access to the EU market (European Commission 2004). Along with financial and technical assistance, preferential trade relations are instrumentalized by the EU as the main incentive it can offer to neighbours (Börzel 2010). The EU operates various trading schemes which bring differential benefits to countries for which they are applied. The most general one, used under the WTO Agreement (former GATT), is the Generalised System of Preferences (GSP). By the means of GSP the EU provides additional trade benefits to countries honouring certain International Labour Organisation (ILO) standards. ${ }^{17}$ For countries of interest the GSP were extended gradually. First, these countries were included in 1995 in a three-year scheme of GSP in respect to certain industrial products. In 1999 the GSP scheme was renewed for another three years and extended to include non-industrial products. Since 2006 the EU has granted Georgia and Moldova with the so-called Generalised System of Preferences Plus (GSP+), which compared to GSP includes more type of products into the scheme. GSP+ is also conditional on compliance with the core ILO and UN conventions. In the case of Moldova, the GSP+ has been upgraded in 2008 to Autonomous Trade Preferences (ATP) which is even more encompassing in terms of included products than GSP+. Finally, the EU has substituted GSP with GSP+ for Armenia and Azerbaijan starting with 2009. However, the most beneficial trading regime with the EU would be a (deep and comprehensive) free trade area, which is negotiated to be set into operation through the next generation of contractual agreements between the EU and ENPC. They are

\footnotetext{
17 "Council Regulation (EC) No. 2820/98 of 21 December 1998 applying a multiannual scheme of generalised tariff preferences for the period 1 July 1999 to 31 December 2001”, Official Journal of the EU, L357/1, 30.12.98.
} 
supposed to cover all trade, provide for the highest possible degree of liberalization, and to offer asymmetric treatment in favour of partner economies.

\section{Visa Regime}

The EU has also pledged to offer to neighbouring countries the prospect of "further integration and liberalization to promote the free movement of persons” (European Commission 2003a). Indeed, a free visa regime with the EU is another attractive incentive for ENPC. The ENPC have long sought to convince the EU so that it lessens the requirements for their nationals to enter the EU. The ENP founding documents set the establishment of visa free regimes as a long-term objective (European Commission 2003a, 2004). Until then however the EU decided to take a gradual approach and concluded in this regard agreements with Moldova and Ukraine, which facilitate the issuance of visa for certain category of citizens. Among the facilitations one could mention a reduced price for visas, less formal documents to be presented at the consular offices of EU Member States, a more rapid examination of submitted visa applications, bona fide principle for those third country nationals who previously respected the return requirements, etc. The Agreements with Moldova and Ukraine on the facilitation of issuance of visa have entered into force in 2008. However, the most attractive incentive in terms of movement of persons would be a free visa regime. The countries of interest wish that the future contractual agreements with EU, to follow after the PCAs, will provide for a free visa travel in the EU.

Summing up, since the launch of the ENP both credibility of incentives put on offer to the Eastern neighbours and the size of these benefits have increased. It might not be the case that the above incentives constitute a "considerable" added value as declared by the EU, ${ }^{18}$ but it is however true that the ENP has led to a modest upgrade of EU incentives to its neighbouring countries. Whether the socialization dimension of EU democracy promotion approach under the ENP became more substantive as well the next subsection turns to.

\subsection{SOCIALIZATION}

\section{EU Programs}

\footnotetext{
${ }^{18}$ European Commission (2004:9).
} 
Since the outset of the ENP, its founding documents envisage gradual opening of certain Community programs to the participation of ENPC in such areas as education, training and youth, research, environment, culture, audio-visual, etc. (European Commission 2003a, 2004). This idea got more support in the period to follow, especially at the end of 2006 on the occasion of a thematic Communication issued in this regard by the European Commission (European Commission 2006h). Participation of ENPC in specific EU agencies and programmes is seen as an additional channel for enhanced communication, by the means of which the new participants would be supported to get socialized into the Community sectoral norms and practices. This participation would also help for better coordination of common interests and concerns.

Though it was long and much talked about ENPC participation in EU's agencies and programmes, there was not much progress achieved in practical terms. With few exceptions, participation in EU's agencies and programmes is still at an exploratory level, being yet evaluated where would be more appropriate for ENPC to partake. In the Eastern Neighbourhood only Moldova and Georgia were invited to take part within the Mobility Partnership in 2008 and 2009 respectively, ${ }^{19}$ the former becoming as well as member of the Energy Community in 2010 .

\section{TAIEX and TWINNING}

TAIEX events and TWINNING projects undergoing in ENPC create a supplementary channel through which EU norms, standards and practices can spread. ${ }^{20}$ Eastern EU neighbours proved to be active participants in these types of activities in the 2005-2010 period. The most active was Ukraine with 139 TAIEX events and 21 TWINNING projects (160), then Moldova with 97 TAIEX and 9 TWINNING activities (106), followed by Georgia with 71 TAIEX and 9 TWINNING activities (80), Armenia with 56 TAIEX and 5 TWINNING activities (61) and finally the least active was Azerbaijan with 20 TAIEX events and 16 TWINNING projects

\footnotetext{
${ }^{19}$ Partnerships require that pilot countries commit themselves to cooperate with the EU on the management of migration flows, while being offered better conditions for legal migration, as well as means to manage circular and return migration (European Commission 2007).

${ }^{20}$ Technical Assistance and Information Exchange (TAIEX) is an instrument that supports partner countries by the means of delivery of appropriate tailor-made expertise with regard to the approximation, application and enforcement of EU legislation. It was extended to the ENPC in 2007. TWINNING programme aims to help beneficiary countries to develop modern and efficient administrations and provides a framework for administrations and semi-public organisations in the beneficiary countries to work with their counterparts in the EU Member States (core teams of long-term seconded experts).
} 
(36). ${ }^{21}$ Here two observations are necessary. First, the more active participation of Ukraine and Moldova in these activities might be explained by their earlier start in implementing the ENPAPs. Second, the leading position of Ukraine in terms of number of activities in which it has participated can be a function of its lager bureaucratic capacity, but not necessarily. Azerbaijan is the second largest country in the region, but at the same time the least active participant in TAIEX events and TWINNING projects.

\section{European Regional Organisations}

The EU and its Member States can also exert an indirect influence on the ENPC in ways of entrapping them in socialization dynamics through sharing the same institutional structures and rules peculiar to different regional arrangements. Particularly important such influence can be in the case of those regional organisations where the EU Member States represent a significant share, such as Council of Europe (CoE), Organisation for Security and Cooperation in Europe (OSCE), Central European Initiative (CEI) and Regional Cooperation Council (RCC). ${ }^{22}$ The expectation here is that the extent of socialization might increase with the duration of presence, but also with the membership instances in those regional arrangements where the EU Member States represent a significant share. Considering the duration and number of membership instances in such regional organisations, one could find out that Moldova is relatively more exposed to socialization dynamics where the EU Member States represent a significant share. The second more exposed country to socialization dynamics within European regional organizations is Ukraine. It is then followed by Georgia, which in its turn is followed by Armenia and Azerbaijan. Interestingly, this exposure to socialization contingency of EU Member States correlates well with the long-term regime patterns in the region considered.

\section{Trade with EU}

Trade with the EU is approached as a proxy for the intensity of interaction between socializer and socializees, and as an indication of the volume of economic flows between the EU and its neighbours. According to the available data, in all cases, but Azerbaijan, the share of trade with the EU in the total trade has increased

\footnotetext{
${ }^{21}$ European Commission (2011), Implementation of the European Neighbourhood Policy in 2010. Sectoral Progress Report, SEC(2011) 645, http://ec.europa.eu/world/enp/documents_en.htm\#3.

22 “Significant share” means in this context at least half of its members. OSCE is the only exception, EU Member States representing 27 out of its 56 total members, among which one is Holy See.
} 
during the ENP period. The same, this time with the only exception of Ukraine, can be said about the bilateral trade in the 1999-2003 period. The most impressive increase in bilateral trade was experienced in the case of Moldova. Since the launch of the ENP, the mean share of bilateral trade with the EU in the total trade was 41.21\% in the case of Moldova, 37.97\% - Azerbaijan, 37.67\% - Armenia, 30.72\% - Ukraine and 24.42\% Georgia.

\section{[Figure 6 about here]}

\section{Proximity to EU}

The ENP was a response to the extension of the EU's borders, to the limits of this extension, and to the opportunities and challenges opened up by the enlargement. Given the EU enlargement some of the partners included in the ENP became direct neighbours of the EU. Ukraine became such a neighbour in 2004, while Moldova in 2007, after Romania (and Bulgaria) joined the EU. In contrast, the ENPC from South Caucasus are disadvantaged yet in establishing direct cross-border communication channels with the EU.

In short, in the post-ENP period the exposure of concerned countries to the dynamics of socialization into the EU norms has also increased. This, along with the upgrade of EU incentives, substantiates the EU democracy promotion under the ENP.

\subsection{CONDITIONALITY AND SOCIALIZATION VS. REgIME PATTERNS}

In the light of the above findings on EU incentive structures and socializations dynamics, the question is now to what extent the EU democracy promotion approach under the ENP has been effective (reflected into greater levels of democratic development) and consistent (more incentives for more progress)? The answer is: rather not effective, ${ }^{23}$ but partly consistent. As the Figure 7 shows, the upward trend across all cases in terms of credibility and size of offered incentives and socialization dynamics is not paralleled by similar trends across all cases in what concerns the long-term regime patters in the region. However, in the individual cases of Georgia and Ukraine this upward trend in incentives and socialization dynamics is paralleled by a similar trend in terms

\footnotetext{
${ }^{23}$ For a similar finding see Kochenov 2008, Boonstra and Shapovalova 2010, Börzel 2010. In the 2011 review of the ENP the EU acknowledges that its support to political reforms in neighbouring countries has met with limited results and that a new approach to build and consolidate “deep democracy” is needed (European Commission 2011a).
} 
of regime patterns, meaning an increase of the democracy level (Figure 7c,e). Hence, the EU was consistent only with regard to these two countries, i.e. their progress in terms of democracy was correspondingly rewarded with upgraded material benefits. The “more for more” principle was partially attained. Surprisingly or not, they are the only countries in the region to experience a so-called "colour revolution" in the mid of 2000'. At that time the ENP was still in infancy, which suggests that the regime patterns in these two cases are not explained by the observed increased incentive structures and socialization dynamics under the ENP. Therefore, one should additionally bring into account domestic arenas and other international factors with which concerned countries interact in the wide international environment. Further research is needed to uncover the synergetic effects of EU democracy promotion, domestic and (non-EU) international factors on the regime patters in the region under scrutiny.

\section{[Figure 7 about here]}

To be sure, the effectiveness of EU democracy promotion in Eastern ENPC appears to get in the 20042010 period close to nil. In what concerns the consistency of financial support, the EU approach can be qualified so only with regard to Armenia (a "less for less” case) and Georgia (a “more for more” case). At the same time, the overall EU incentive structure under the ENP was consistent only in the case of Georgia and Ukraine. Their democratic progress was paralleled by an increase in the offered material benefits. For the rest of cases the EU has upgraded its incentive structures on offer, despite stagnation or opposite trends in terms of democratization.

Nevertheless, if one zooms out and considers a longer period since the early 1990’ until 2010, it appears that the EU democracy promotion approach to the entire this region was largely consistent. The Figure 8 shows that differential performance of Eastern ENPC in what concerns respect for democratic principles, human rights and the rule of law in the entire 1991-2010 period was largely consistently rewarded by the EU.

\section{[Figure 8 about here]}

Though the offered benefits are relatively modest, one could see that the higher the democratic progress (Figure 8a), the higher the incentive structures provided (Figure 8b). Ukraine stands out in this respect as the only "mistreated" neighbouring country in the East. In addition, the association between regime patterns and extent of socialisation with the EU in the 1991-2010 period is even stronger. Generally, one can conclude that in 
cases of higher incentive structures and more intense socialization with the EU the democratic standards appear to be higher. Moldova and Ukraine are the cases in point. Georgia and Armenia follow at a close distance, while Azerbaijan significantly laggards behind. This however does not prove yet the hypothesised causal relationship (§2), but it gets in the line of a more general argument which reads that regime patterns vary with the extent of leverage the democratic West exerts over transitioning countries and linkage between them (Levitsky and Way 2005, 2010). The Figure 8 makes clear the case that on the long run a form of spatial dynamics gets expressed in the regime patterns, but the geographical proximity of Moldova and Ukraine to the EU is not necessarily to be seen as the determinant causal force. However, the important role it plays is that is creates a favourable environment where communication channels can naturally emerge, through which a variety of (ideational) exchanges may occur in iterated interactions. Proximity is thus important to the extent it can encourage for communication bridges to being established and used in durable bilateral interactions. Without proper communication channels it would not count much.

In a nutshell, the EU democracy promotion under the ENP proved to be rather not effective, but partly consistent. The claim about effectiveness under the ENP comes at odds with the long-term processes which display a striking association between incentive structures and extent of socialization with regimes patterns on the long run. Therefore, to double-check the finding concerning the effectiveness of EU democracy promotion under the ENP the next section turns to an evaluation of the way in which Eastern ENPC responded to the EU through the implementation of the democracy-related objectives of the ENPAPs.

\section{ENPAPS}

This section provides a content analysis of Progress Reports (hereafter: PR) released by the European Commission on the implementation process of relevant objectives from the ENPAPs. Before this, few words about the implementation process of ENPAPs are in order.

The ENPAPs are political documents, which substantiate the cooperation process within the ENP in a number of important areas. They spell out priorities of bilateral cooperation, objectives and actions/ measures to be implemented in such areas as: political dialogue and reform; economic and social reform; trade, market and regulatory reform; Justice and Home Affairs (JHA); transport, energy, information society, environment, research and innovation; people-to-people contacts. Though they share a common template, their substance is differentiated, reflecting the existing state of relations with partner countries, their special needs and capacities, 
as well as common interests. The ENP founding documents propose that Action Plans set out clear objectives and benchmarks by which progress can be monitored and judged against agreed targets (European Commission 2003a). The ENPAPs with Moldova and Ukraine have been concluded in February 2005 for a period of three years, while those with Armenia, Azerbaijan and Georgia were concluded in November 2006 for a period of five years. At the beginning of 2008 it was decided that the ENPAPs with Moldova, Ukraine and Israel should be rolled-over "for one year with, no change in substance”, pending the future contractual agreements (European Commission 2007). Subsequently, it was accepted that the ENPAPs will continue to guide the development of bilateral relations until new contractual agreements will be in place. In the case of Ukraine, the EUUAP was substituted in November 2009 by an Association Agenda, meant to prepare Ukraine for the entry into force of the Association Agreement. In terms of its democracy-related content the Agenda does not put forward substantially new objectives compared to the EUUAP. From this point of view, the Agenda might be seen as a placebo for mitigating Kiev’s misgivings with a too long awaited Association Agreement. ${ }^{24}$

For the evaluation process of the ENPAPs it was established that their implementation should be monitored within the existing institutional structures as instituted by the PCAs and by the European Commission which should report periodically on progress achieved.

\subsection{IMPLEMENTATION OF ENPAPS}

The first section of ENPAPs, "Political dialogue and reform”, includes sub-sections dedicated to democratic institutions, the rule of law, human rights and fundamental freedoms. What is of interest here it is the extent to which ENPC have considered complying with the objectives and actions of the ENPAPs in these areas. One way to do so is to juxtapose the relevant content of ENPAPs with the Commission's Progress Reports. Given the fact that Commission's monitoring reports are broader in their scope and coverage, for a better precision in tracking the ENPC willingness to implement the democracy-related content of the Action Plans, it is advisable to concentrate on those objectives and actions which originally were part of the Plans.

\section{Democratic Institutions, the Rule of Law, Human Rights and Fundamental Freedoms}

\footnotetext{
${ }^{24}$ Negotiations on a new agreement to replace the PCA were launched with Ukraine in March 2007. Similar negotiations were launched with Moldova in January 2010, and with Armenia, Azerbaijan and Georgia in July 2010.
} 


\section{Armenia}

The Commission's Progress Reports suggest that 2007 was the most successful year in the implementation of the EUArAP. In the following period this process has slowed down. Commission's report for the 2007 informs that the implementation of a package of legislative reforms led to the improvement of the legislative framework regarding, among others, the separation of powers (including increased powers for the National Assembly), the independence of the judiciary, the Human Rights Defender (HRD) and freedom of the media (PR Armenia 2008).

The European Commission assesses as a good progress the administration of the 2007 parliamentary elections and the first elections of the Mayor and Council of Elders of Yerevan in May 2009. Concerning the party system, the Commission welcomes the creation in 2007 of a body to monitor party financing. ${ }^{25}$ Good progress was achieved in 2007 as well as on the rule of law dimension, particularly through the introduction of a new judicial administration structure, limiting the scope of the Prosecutor's office power, initial steps towards the establishment of a free legal aid system, and the establishment of a system of continuous training for judges and prosecutors. The report for 2010 points to the enhancing transparency of the court system, but also to the lack of progress in what concerns the independence of judiciary (PR Armenia 2011).

As requested by the EUArAP, the Criminal Code was revised in 2008 to include articles on active and passive corruption in line with the relevant CoE and UN conventions, judges' salaries were increased in 2007 and 2009, codes of ethics were put in place for judges, prosecutors and police officers, and important steps were taken to improve the anticorruption legislative framework (PR Armenia 2008, 2009, 2010). Equally, in response to the CoE's Group of States against Corruption (GRECO) recommendations, the decisive role of the Prosecutor General in the initiation of proceedings was abolished and the immunity of prosecutors was lifted (PR Armenia 2011).

In the area of human rights and fundamental freedoms the EU praised the launch in 2009 of a regular human rights dialogue with Armenia, strengthening the role of the Human Rights Defender in terms of its capacity to investigate claims of violations and involvement in the legislative process and organisation of specialised trainings for police staff and civil servants on human rights issues (PR Armenia 2008, 2009, 2010, 2011).

\footnotetext{
${ }^{25}$ For the sake of precision, one should mention that the EUArAP asks for "clear and transparent rules on party financing" (emphasis in Italics: S.B.).
} 
The European Commission reports also legislative improvements to the law on rallies and that less applications submitted by the opposition to organise rallies were rejected in 2009 compared with the previous years (PR Armenia 2009, 2010). Equally, it has reported some progress on enhancing the freedom of expression such as decriminalisation of defamation and that important steps were taken in improving cooperation with civil society (PR Armenia 2009, 2010, 2011).

\section{Azerbaijan}

Azerbaijan proved to be the most unwilling ENPC in the East to move ahead with democratic reforms. Commission's reports mention that overall there was no or limited progress in the implementation of the EUAzAP in such areas as democracy, rule of law, human rights and fundamental freedoms (PR Azerbaijan 2008, 2009, 2011).

With regard to electoral process, the Commission informs that presidential elections in October 2008 demonstrated some progress towards meeting OSCE commitments and other international standards, and that following the local elections held in December 2009 the number of women winning seats in municipal councils rose sharply, given the conscious intention of both ruling and opposition parties to increase female participation (PR Azerbaijan 2009, 2010). However, it is considered that parliamentary elections held in November 2010 failed to capitalize on the previous limited advances in this area, except an increase in the number of female members of the parliament (PR Azerbaijan 2011). In the field of judiciary reform the few positive assessments concern progress on the selection of judges, training of judiciary staff, increase in salaries and adoption of code of ethics for judges, the selection procedure of the Bar Association, establishment of the Academy of Justice and of Administrative Courts (PR Azerbaijan 2008, 2009, 2010, 2011). In line with the Action Plan requirements, a follow-up to the state programme on fighting corruption for the 2004-2006 was devised for the subsequent 20072011 period (PR Azerbaijan 2009). Equally, anticorruption measures were taken in the field of interinstitutional cooperation, direct reporting of corruption cases has been introduced and there was a progress in meeting several recommendations of GRECO with regard to public sector human resources management issues (PR Azerbaijan 2008, 2010, 2011). Nevertheless, in public perception the level of corruption has increased in 2008-2010.

Actions in the field of human rights have been limited to such measures as the adoption of an action plan for the protection of human rights in December 2006, upgrading the administrative status of the Ombudsman Institution in July 2007, which plays an active role on low-key issues, but nevertheless avoids 
confronting matters with political repercussions. Apart from the adoption of the "Concept for state support for the development of media in Azerbaijan” in July 2008 and creation of a state support fund for mass media in April 2009 nothing else positive is reported in the field of freedom of expression and mass media (PR Azerbaijan 2009, 2010, 2011). On civil society the Commission reports the establishment of the Council for State Support to NGOs in December 2007 and the significant increase of state funding for NGOs (PR Azerbaijan 2008, 2009). ${ }^{26}$ Commission reports also legislative improvements with regard to freedom of assembly, which remains however very much restricted in practice, a largely secured freedom of religion and efforts to promote gender equality and empowerment of women (PR Azerbaijan 2008, 2009, 2010, 2011).

\section{Georgia}

As in the case of Armenia, the implementation of the EUGAP was more successful in 2007. The difficult situation after the Georgian-Russian war in August 2008 has redirected the attention of Georgian authorities from the reform agenda agreed with the EU. This situation could seemingly be redressed only in 2010.

With regard to the electoral process, among the positive developments introduced before the early parliamentary elections in May 2008, the Commission mentions the lowering of the electoral threshold from 7 to $5 \%$, significant revision of the electoral rolls, better representation for the opposition parties in the electoral commissions, and simplified procedures for filling electoral complaints (PR Georgia 2009). According to international observers, local elections, held in May 2010, marked evident progress towards meeting international standards. Following the political crisis in the aftermath of the Georgian-Russian war, the opposition participation in parliamentary committees was increased, representatives of opposition forces were included in the constitutional reform process, in the High Council of Justice, and in the parliamentary supervision over defence and security matters (PR Georgia 2009).

All Commission's reports qualify as (good/ major) progress the reforms promoted in the rule of law and fight against corruption fields (PR Georgia 2008, 2009, 2010, 2011). As required by the EUGAP, a new free legal aid service with branches in most Georgian regions was established, Georgia made progress in reforming its criminal justice system through the adoption in October 2009 of a new Criminal Procedure Code, introducing

\footnotetext{
${ }^{26}$ Problematic remain however the appointment of members of this council, which is under the control of the President, and criteria for grant allocation (PR Azerbaijan 2008).
} 
jury trials in criminal cases (PR Georgia 2010). Among other important measures the Commission mentions the adoption in July 2007 of the law on the rules of communication with judges of general courts, which obliges judges to report to the High Council of Justice on any attempt to influence the court. The latter institution was removed from under the President's responsibility and integrated fully into the judiciary, and a High School of Justice was established (PR Georgia 2008, 2009). According to the Commission’s evaluation, Georgia made significant efforts to comply with GRECO recommendations on fight against corruption (PR Georgia 2010).

Implementation of the human rights-related part of the EUGAP is also reported to be better ensured in 2007 and seemingly in 2010. In accordance with the EUGAP, the Commission mentions that the Office of the Public Defender was strengthened in 2009 and 2010 (PR Georgia 2010, 2011). The Commission also reports that Georgian Public Broadcaster covered the period of local elections organized in May 2010 in a more balanced manner compared to previous election periods (PR Georgia 2011). In what concerns gender equality, a corresponding law was adopted in March 2010 ensuring better condition for the political participation of women.

\section{Moldova}

Moldova took seriously its obligations assumed under the EUMAP, aligning its governmental programme, adopted in April 2005, to the provisions contained in the Plan. In contrast to Armenia and Georgia who had a good start in the first year of ENPAPs implementation process, Moldova was more constant in delivering results across the entire period in which its corresponding Action Plan had to be implemented. However, a setback could be witnessed in the mid of 2007 until the second half of 2009. The Commission has evaluated the actions undertook in 2010 as successful on both adoption and implementation dimensions of EUMAP (PR Moldova 2011).

European Commission reports that the Action Plan's request on the reform of parliamentary immunity was honoured in December 2006 as recommended by the Parliamentary Assembly of the Council of Europe (PACE), Moldova's good record in organizing elections in line with most OSCE and CoE standards and an increase in the transparency of the decision-making process (PR Moldova 2008, 2010, 2011).

The Commission qualifies as progress the reform of the judicial system, through which the capacities of the Supreme Council of Magistracy (SCM) were consolidated, a Department for Judicial Administration was created, the National Institute of Justice was established, the code of ethics for judges was approved, and a judicial inspection system under the aegis of the SCM was introduced (PR Moldova 2008, 2009). As required by 
the Action Plan, in 2007 it was adopted the law on mediation, establishing an alternative mechanism of voluntarily solving civil and criminal cases between parties and setting rules for the status of professional mediators, and the law on state guaranteed legal aid (PR Moldova 2008).

The Action Plan requires that Moldova implements the recommendations of GRECO. In this regard, GRECO concluded in December 2008 that “significant progress” had been achieved on its recommendations, but that further work is still needed (PR Moldova 2009, 2010, 2011). To this, the European Commission reported subjecting new laws to anticorruption screening before their adoption, entering into force and adoption of a number of corruption-related laws (PR Moldova 2008, 2009). ${ }^{27}$ Worthwhile is also mentioning that Moldova has improved its ranking in terms of perceived corruption, but that the track-record of high level corruption cases remains unsatisfactory.

On the human rights dimension, the Commission informs about the abolition in 2006 of the death penalty, and - as requested by the Action Plan - organisation of trainings for judges, bailiffs and prosecutors on human rights matters (PR Moldova 2006, 2009). Although the media-related legislation provide a good legislative basis to ensure respect for the freedom of media and expression (PR Moldova 2008), the real situation in this regard improved only in the last quarter of 2009 and 2010. The same is valid for the access to information of public interest. The law on public assembly, which according to the EUMAP had to be brought in line with the requirements of the ECHR, was adopted in February 2008 and has been positively assessed by the CoE and OSCE (PR Moldova 2008, 2009). In what concerns the dialogue and cooperation with civil society, the European Commission praises the launch of the National Council for Participation as a forum between the executive and civil society, and the adoption of the strategy on the development of civil society in 2008-2011 (PR Moldova 2008, 2009, 2010). Moldova has also adopted the law on equal opportunities for women and men, and continued its efforts towards the promotion of women's participation in the political life (PR Moldova 2006, 2008).

\section{Ukraine}

\footnotetext{
${ }^{27}$ Entered into force: laws on political parties, on conflict of interest, on preventing and combating corruption; adopted: law on the protection of witnesses and process participants, Code of ethics for civil servants, etc.
} 
Ukraine had the most promising start in implementing the EUUAP, but it slowed down the rhythm in 2007 due to continuing political instability. Ukraine is the only ENPC to sign an Association Agenda, but its implementation process in 2010 lacked enough determination on the part of Ukrainian authorities.

Despite political instability, Ukraine managed to consolidate its positive record in conducting overall free and fair elections in 2006, 2007, 2010, which makes the European Commission to underline the "significant progress which has taken place in Ukraine’s democratic development” (PR Ukraine 2006, 2008, 2010). In the words of Commission, inclusive candidate registration and a vibrant media environment provided for an open and competitive environment which enabled voters to make informed choices and to freely and fairly express their will (PR Ukraine 2006, 2008). If this was still the tone for the 2010 presidential elections, local elections held in October 2010 were criticized as being a step backward compared with other post-2005 elections (PR Ukraine 2011).

Considerable steps have been taken towards consolidating the rule of law in the first two years since the start of the EUUAP implementation (PR Ukraine 2006). Among the most notable developments in line with the EUUAP in the field of judiciary reform the Commission mentions entering into force of the new codes on administrative justice and civil procedure and the introduction of a "Concept on the reform of the office of prosecutor” which takes into account CoE recommendations (PR Ukraine 2006, 2009). As requested by the EUUAP, Ukraine joined GRECO, adopted a revised version of its national anti-corruption strategy in 2006, and, as a result of recommendations addressed by GRECO, has created an interagency working group on anticorruption issues, and decided to establish the post of Governmental agent for anti-corruption policy in 2008 (PR Ukraine 2006, 2009).

If the 2006 Progress Report informs that the situation of human rights in Ukraine improved considerably, the Report for 2010 indicates a negative trend in this regard. In line with the EUUAP, which requires effective implementation of ECHR judgements, Ukraine has adopted the law on the enforcement of judgements of the ECHR, which was a precedent within the CoE (PR Ukraine 2006). Equally, in accordance with the Plan there have been organized trainings on human rights issues for judges and there were efforts to ensure gender equality (PR Ukraine 2006, 2008, 2010, 2011). The European Commission reports also that the freedom of media has been consolidated, Ukrainians enjoyed wide-ranging pluralism in both electronic and print media, but that this media environment has deteriorated in 2010 (PR Ukraine 2008, 2009, 2011). Moreover, Ukraine has taken “considerable steps” in improving the development of civil society (PR Ukraine 2008). The 
registration fee for NGOs was lowered, and a concept paper and a corresponding action plan on the development of civil society in Ukraine were approved in 2007 and 2008 (PR Ukraine 2008, 2009).

Summing up, this evidence suggests that most Eastern ENPC were, with different success, trying to comply with the ENPAPs' provisions. ${ }^{28}$ Despite the apparent ineffective EU democracy promotion under the ENP, it is evident that most partners have considered in their reform agendas the democracy-related objectives of the ENPAPs. Generally, they achieved more progress in the initial period after their signature and mainly on the law adoption dimension. Equally, according to the Commission's evaluations, the progress in the economic sphere was more important than that in the area of democratic governance. On the other hand, many problems appear to be reported in the context of elections, which along with the overall regime patterns in the countries of interest suggest that in what concerns norm internalization the record is far from satisfactory.

\subsection{ADOPTION OF INTERNATIONAL DEMOCRATIC INSTRUMENTS}

The ENP documents propose that "key benchmarks should include the ratification and implementation of international commitments which demonstrate respect for shared values, in particular the values codified in the UN Human Rights Declaration, the OSCE and Council of Europe standards” (European Commission 2003a). In this vein, the ENPAPs make reference to a number of international instruments launched by the UN and CoE in the field of democracy and human rights, whose ratification and transposition into national legislations were assumed by the ENP partner countries. Making explicit reference to these international instruments the EU reinforces the leverage of these organisations. The extent to which countries of interest ratify these international instruments give a supplementary account on their willingness to adopt the EU promoted democratic norms.

The EUArAP requests that Armenia ratifies and implement the Optional Protocol to the UN Convention against Torture and Other Cruel, Inhuman or Degrading Treatment or Punishment (CAT-OP). Interestingly, Armenia had ratified this international instrument in September 2006 before the EUArAP was signed in November the same year. The EUArAP also requires that Armenia brings the corruption-related provisions of the Criminal Code in line with UN Convention on Corruption (ratified in March 2007), the CoE Criminal Law Convention on Corruption and Civil Law Convention on Corruption (both ratified before the signature of the

\footnotetext{
${ }^{28}$ Apart from this evidence, there were remarkable developments that indicate that in some situations the EU did have decisive influence on its neighbours. For example, when PRO-TV, an important independent television channel in Moldova, came close to being disposed in 2008 of its broadcasting license by the national broadcasting regulator, the only pressure from the EU and other external actors avoided the disruption of its service (PR Moldova 2009).
} 
EUArAP) and the OECD Convention on Combating Bribery of Foreign Public Officials in International Business Transactions (not ratified). In total since the launch of the EUArAP, Armenia undertook 1 action (1 ratification) with regard to $1 \mathrm{CoE}$ instrument in the field of human rights and 6 actions (4 signatures and 2 ratifications) with regard to $5 \mathrm{UN}$ instruments in the field of human rights and fight against corruption. ${ }^{29}$

In line with the EUAzAP foreseen actions, Azerbaijan has ratified in February 2009 CAT-OP. The EUAzAP requires also that Azerbaijan brings the corruption-related provisions of the Criminal Code in line with the same international instruments mentioned above in the case of Armenia. All these instruments, with the exception of the OECD Convention on Combating Bribery of Foreign Public Officials in International Business Transactions, were ratified by Azerbaijan before the EUAzAP was signed. Following the signature of the EUAzAP, Azerbaijan has undertook 2 actions (1 signature and 1 ratification) in relation with 1 CoE instrument in the field of human rights, and undertook 8 actions ( 1 acceptance, 3 ratifications, 4 signatures) with regard to 6 UN instruments in the field of human rights.

The EUGAP demands that Georgia accedes to the UN Convention on Corruption, ratifies the CoE Criminal Law Convention on Corruption and ensures that domestic legislation is in line with the above mentioned international instruments, the CoE Civil Law Convention on Corruption and the OECD Convention on Combating Bribery of Foreign Public Officials in International Business Transactions. Georgia has ratified in January 2008 the CoE Criminal Law Convention on Corruption and acceded in November 2008 to the UN Convention on Corruption. The Action Plan requires also that Georgia signs and ratifies European Charter for Regional or Minority Languages, which by the end of 2010 still awaited these actions. In total since the launch of the EUGAP, Georgia has undertook 3 actions (2 ratifications and 1 signature) with regard to $3 \mathrm{CoE}$ instruments in the field of corruption and human rights, and 4 actions ( 2 accessions and 2 signatures) with regard to $4 \mathrm{UN}$ instruments in the same fields.

The EUMAP requests that Moldova signs and ratifies the following UN conventions and related optional protocols: Optional Protocol to the International Covenant on Civil and Political Rights (CCPR-OP1); Second Optional Protocol to the International Covenant on Civil and Political Rights, aiming at the abolition of the death penalty (CCPR-OP2-DP); Optional Protocol to the Convention on the Elimination of All Forms of Discrimination against Women (CEDAW-OP); Convention against Torture and Other Cruel, Inhuman or Degrading Treatment or Punishment (CAT) - Declar.Art.21, Declar.Art.22; CAT-OP; International Convention on the Protection of the Rights of All Migrant Workers and Members of their Families (MWC) and ratifies:

\footnotetext{
${ }^{29}$ See Appendix 1.
} 
Optional Protocol to the Convention on the Rights of the Child on the involvement of children in armed conflict (CRC-OP-AC); ${ }^{30}$ Optional Protocol to the Convention on the Rights of the Child on the sale of children, child prostitution and child pornography (CRC-OPSC). With the only exception of MWC, Moldova has fully complied with the signature and ratification commitments in the Action Plan. Since the launch of the EUMAP, Moldova has undertook 6 actions (4 ratifications and 2 signatures) with regard to 5 CoE instruments, and 11 actions (2 accessions, 5 ratifications and 4 signatures) with regard to 8 UN instruments in the field of human rights and fight against corruption.

Finally, EUUAP foresee that Ukraine signs and ratifies CCPR-OP2-DP; CAT - Declar.Art.21, Declar.Art.22; CAT-OP; MWC; Convention and Protocol relating to the Status of Refugees (CSR and CSRProt), ${ }^{31}$ and ratifies: CEDAW-OP; CRC-OP-AC. As in the case of Moldova, with the only exception of MWC, all these instruments were signed and/ or ratified by Ukraine. Overall, since the launch of the EUUAP, Ukraine undertook 11 actions (9 ratifications and 2 signatures) with regard to 9 CoE instruments, and 10 actions (1 accession, 5 ratifications and 4 signatures) with regard to 7 UN instruments in the field of human rights and fight against corruption.

In total with regard to both CoE and UN instruments Ukraine is leading with 21 actions undertook after its corresponding Action Plan started to be implemented. It is then followed by Moldova with 17 actions, which is followed by Azerbaijan with 10 actions, which in its turn is followed by Armenia and Georgia each with 7 actions. $^{32}$

In short, although it is not straightforward to say that all these actions have been taken due to ENPAPs, the adoption of international democratic norms in line with the ENPAPs provisions, especially in the case of Ukraine and Moldova, is evident. The absence of the membership perspective was not an insurmountable impediment in this regard (cf. Freyburg et al. 2009). They do acted, though not successfully enough, in line with the ENPAPs under conditions of more intense patterns of socialization with the EU. The adoption of norms however does not lead immediately and irreversibly to norm internalization, which is largely the case of the

\footnotetext{
${ }^{30}$ CRC-OP-AC was ratified in April 2004.

${ }^{31}$ Ukraine acceded to the CSR and CSR-Prot in 2002. The reason why the EUArAP, EUAzAP, EUMAP and EUUAP require ratification of or accession to some international instruments already ratified or acceded to before the signature of these documents remains largely a mystery.

${ }^{32}$ In what concerns the number of $\mathrm{CoE}$ and UN instruments ratified or to which countries of interest have accessed to in the field of human rights and fight against corruption, Ukraine is leading with 48 instruments. It is then followed by Georgia and Moldova each with 41 instruments, which are in their turn followed by Armenia with 40 instruments and, finally, comes Azerbaijan with 39 instruments.
} 
examined ENPC. Indeed, if in the case of some well-known international norms (e.g. women suffrage) it was necessary for about a century until internalization - as the last stage of their "life cycle" - came about, ${ }^{33}$ it might be too early to expect rapid norm internalization on the part of ENPC.

\section{CONCLUSIONS}

This paper evaluates the extent to which EU democracy promotion approach under the ENP has been effective and consistent. Cases considered are all Eastern partners of the EU involved in the ENP: Armenia, Azerbaijan, Georgia, Moldova and Ukraine. The paper finds out that the increased incentive structures and more intense socialization dynamics in which Eastern ENPC have been brought in since the launch of the ENP are not reflected into higher levels of democracy. Georgia and Ukraine are the only countries where this upward trend in incentive structures and socialization dynamics is paralleled by an increase in the level of democracy. However, their way towards higher democratic standards has been opened up by “colour revolutions” which hit their respective political regimes when the ENP was still in infancy. Therefore, one could hardly assume that their democratic progress was driven by the EU democracy promotion approach under the ENP.

The EU was consistent in deploying the ENP only with regard to Georgia and Ukraine rewarding their relative performance with increased material benefits, compared to those provided before 2004. In the rest of cases the EU has provided increased benefits under the ENP in the absence of sustained or any democratic progress. However, zooming out and considering a longer period from 1991 to 2010 one could find out that the EU democracy promotion approach to the region under focus was largely consistent. The size of incentive structures provided by the EU along this time-frame mirrors largely individual performances registered on the democratization front. The only "mistreated" country in the East is Ukraine. In addition, there is even a stronger association between individual regime patterns in the region and the extent to which cases under scrutiny have been caught into the EU socialisation “entrapment”.

Though the effect of EU democracy promotion approach under the ENP appears to be closed to nil, the most Eastern ENPC have considered in their reform agendas the democracy-related objectives of the ENPAPs. The ENPC have also sought to adopt international instruments in the field of democracy and human rights as provided for in the ENPAPs, especially Ukraine and Moldova which display more intense patterns of socialization with the EU. These, in the light of the observation that "developing democracy in not like making

${ }^{33}$ Cf. Finnemore and Sikkink (1998). 
instant coffee", ${ }^{34}$ suggest that one should be cautious while totally sweeping away the EU's role. At the same time, the resistance of existing regimes in the region to internalize democratic norms given the increased incentives structures by the EU and the more intense socialization dynamics under the ENP requires an assessment of the domestic contexts and of the role of alternative (non-EU) international factors.

${ }^{34}$ Patten (2004). 


\section{FIGURES}

\section{Figure 1.}

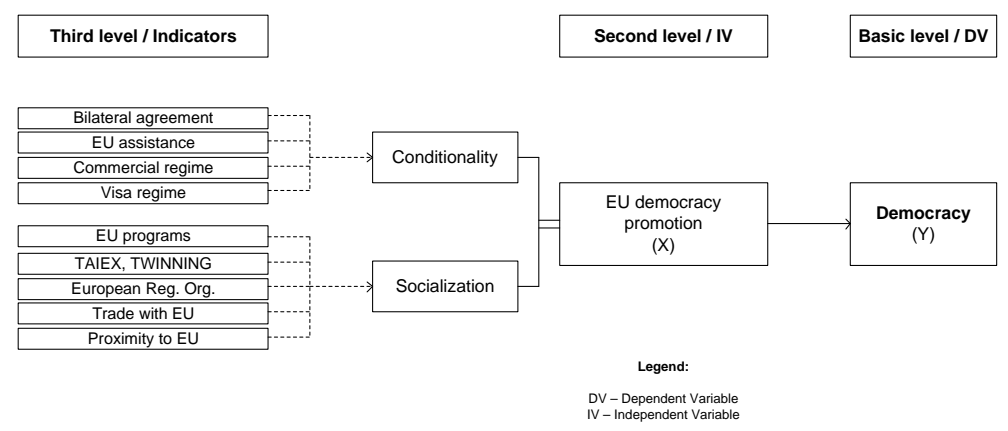

Figure $2 .^{35}$

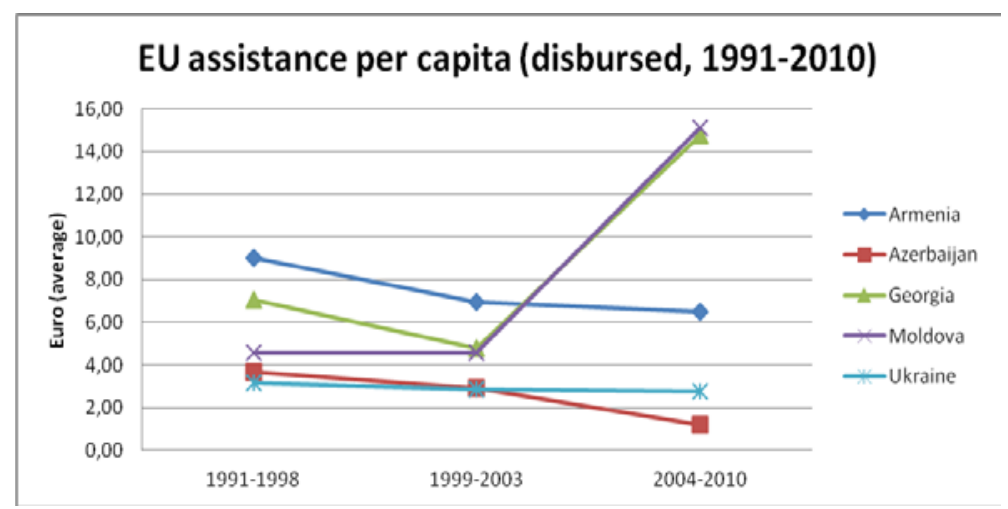

\footnotetext{
${ }^{35}$ Sources: Armenia: European Commission (2001), Country Strategy Paper 2002-2006 and National Indicative Programme 2002-2003, Republic of Armenia, European Commission (2005), European Neighbourhood Policy, Country Report, Armenia, COM(2005) 72 final, SEC(2005) 285/3; Azerbaijan: European Commission (2010), EU Assistance to Azerbaijan 1992-2009, http://ec.europa.eu/delegations/ azerbaijan/eu_azerbaijan/tech_financial_cooperation/index_en.htm; Georgia: European Commission (2005), European Neighbourhood Policy, Country Report, Georgia, COM(2005) 72 final, SEC(2005) 288/3, European Commission (2010), EU Assistance to Georgia 19922009, http://eeas.europa.eu/delegations/georgia/documents/eu_georgia/eu_assistance_to_ georgia_1992_2009_en.pdf; Moldova: European Commission (2004), European Neighbourhood Policy, Country Report, Moldova, COM(2004), 373 final, SEC(2004) 567, European Commission (2006), European Neighbourhood and Partnership Instrument. Republic of Moldova. Country Strategy Paper 2007-2013; Ukraine: European Commission (2006), European Neighbourhood and Partnership Instrument. Ukraine. Country Strategy Paper 20072013; All countries: EuropeAid Annual Reports for 2007-2010, http://ec.europa.eu/europeaid/multimedia/publications/index_en.htm.
} 
Figure 3.

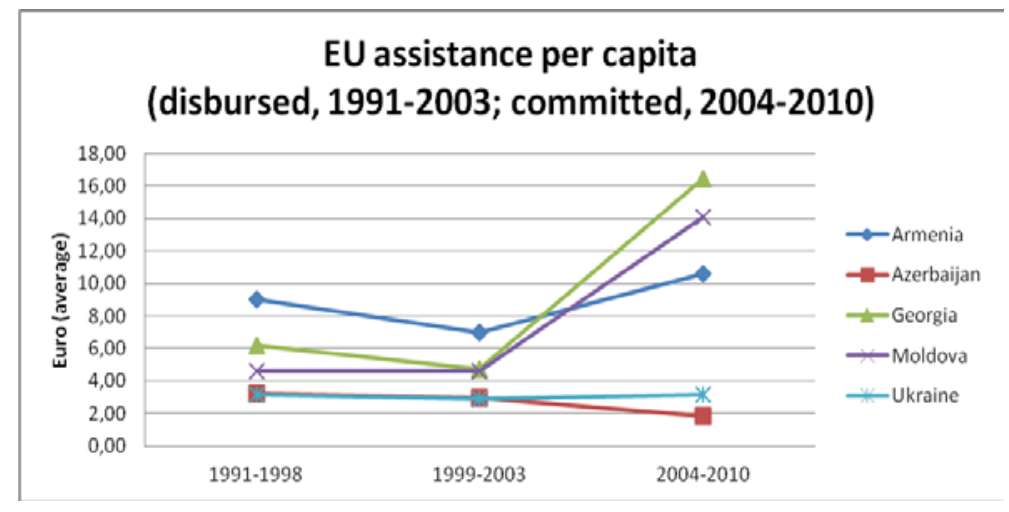

Figure 4. ${ }^{36}$
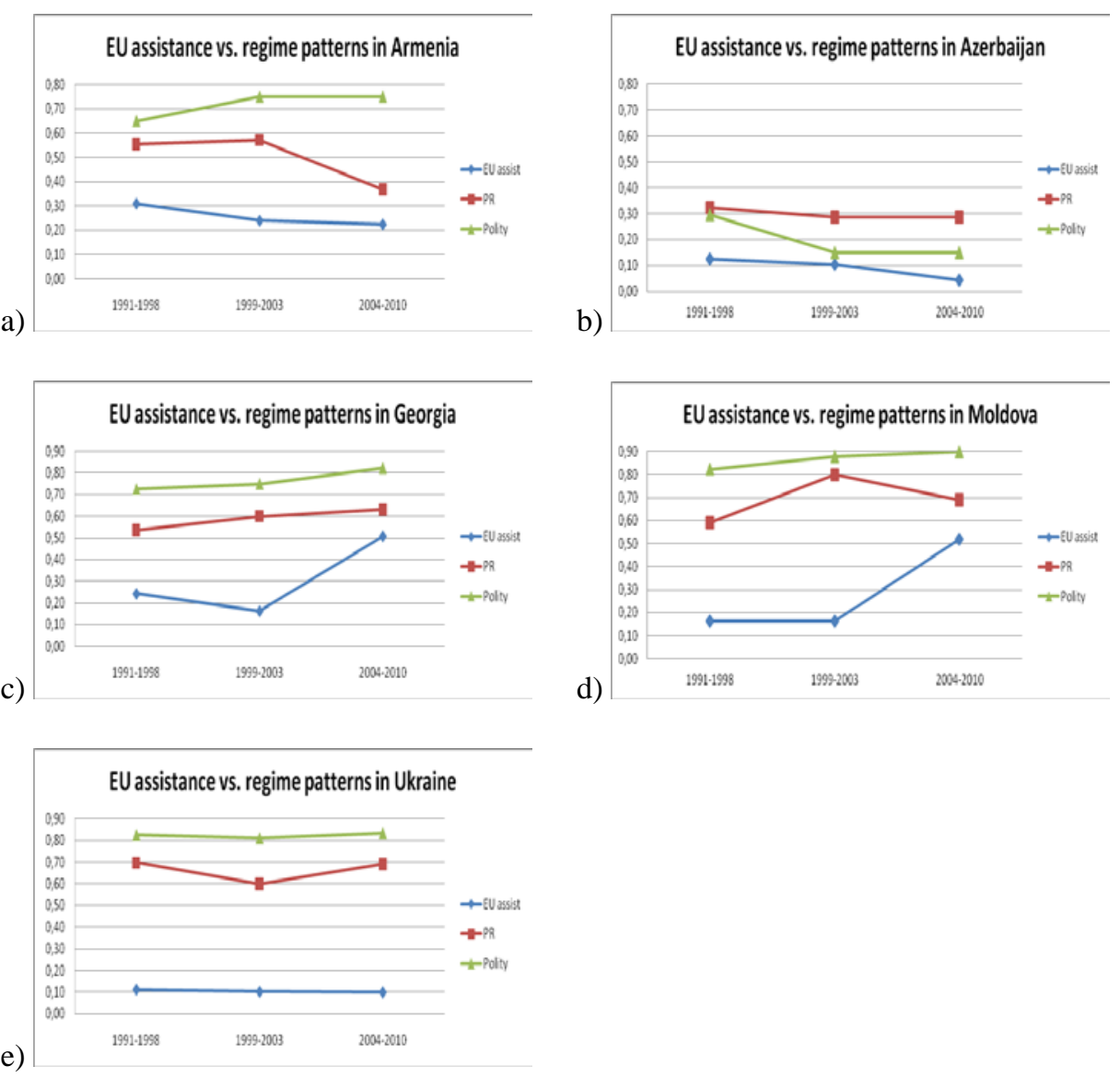

d)

e)

\footnotetext{
${ }^{36}$ Data on EU assistance per capita, PRs and Polity scores have been calibrated and brought into a 0-1 interval. The values for 1991-1998, 1999-2003 and 2004-2010 represent aggregated sub-periods means. For details on calibration strategies see Appendix 2.
} 
Figure 5.

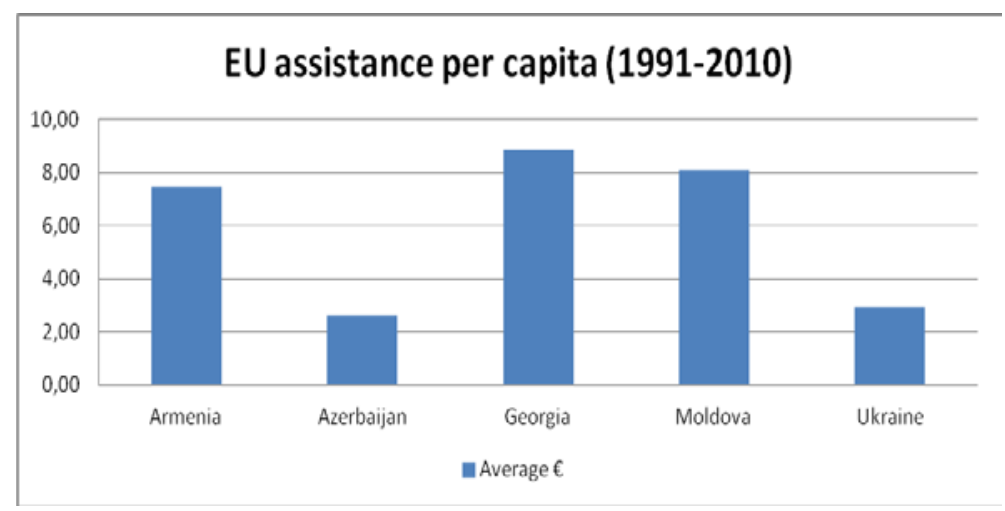

Figure 6.

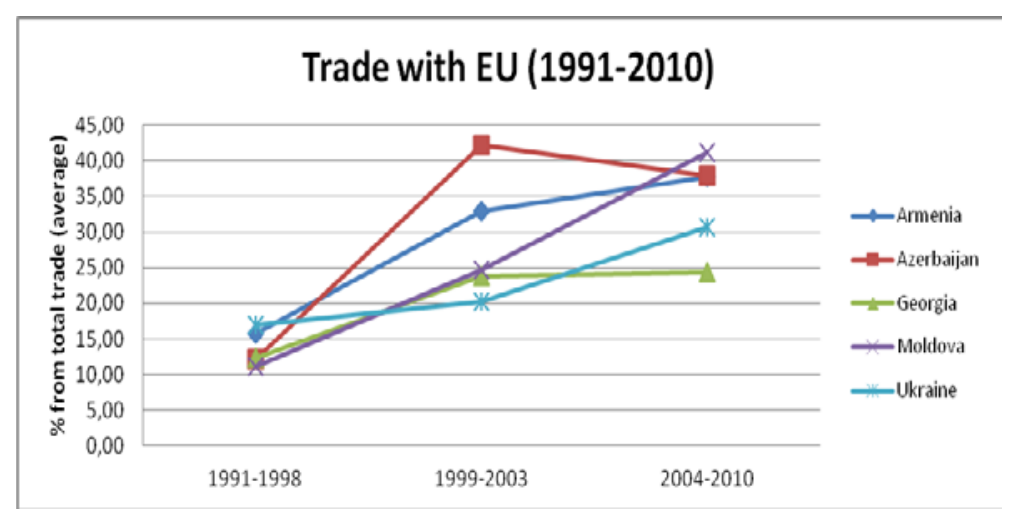

Source: DOTS (IMF).

Figure 7. ${ }^{37}$

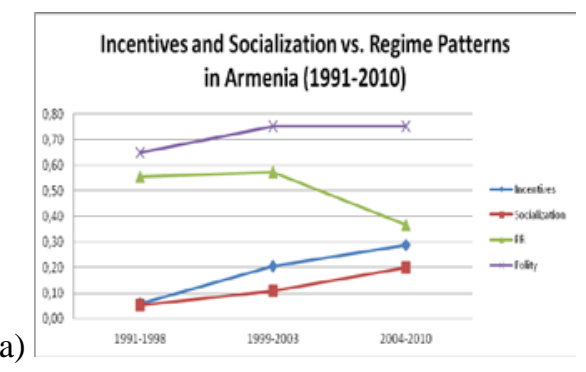

b)

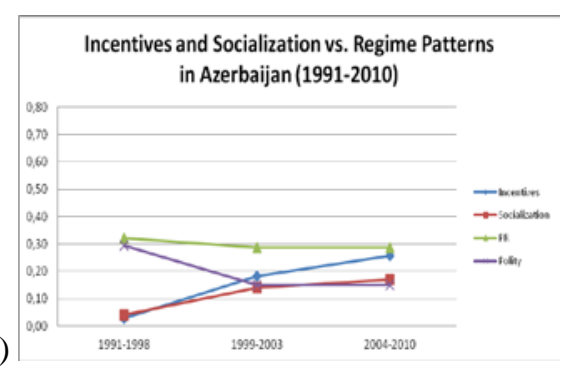

\footnotetext{
${ }^{37}$ Data on indicators corresponding to the conditionality (incentives) and socialization dimensions, as well as PRs and Polity scores have been calibrated and brought into a 0-1 interval. The values on conditionality have been arrived at after averaging across indicators referring to the incentive size (EU assistance per capita, commercial and visa regimes) and then a second averaging across the resulting values and those relating to the incentive credibility (bilateral agreement). The values on socialization have been arrived at after averaging across its corresponding indicators. The values for 1991-1998, 1999-2003 and 2004-2010 represent aggregated sub-periods means. For details on calibration strategies see Appendix 2.
} 

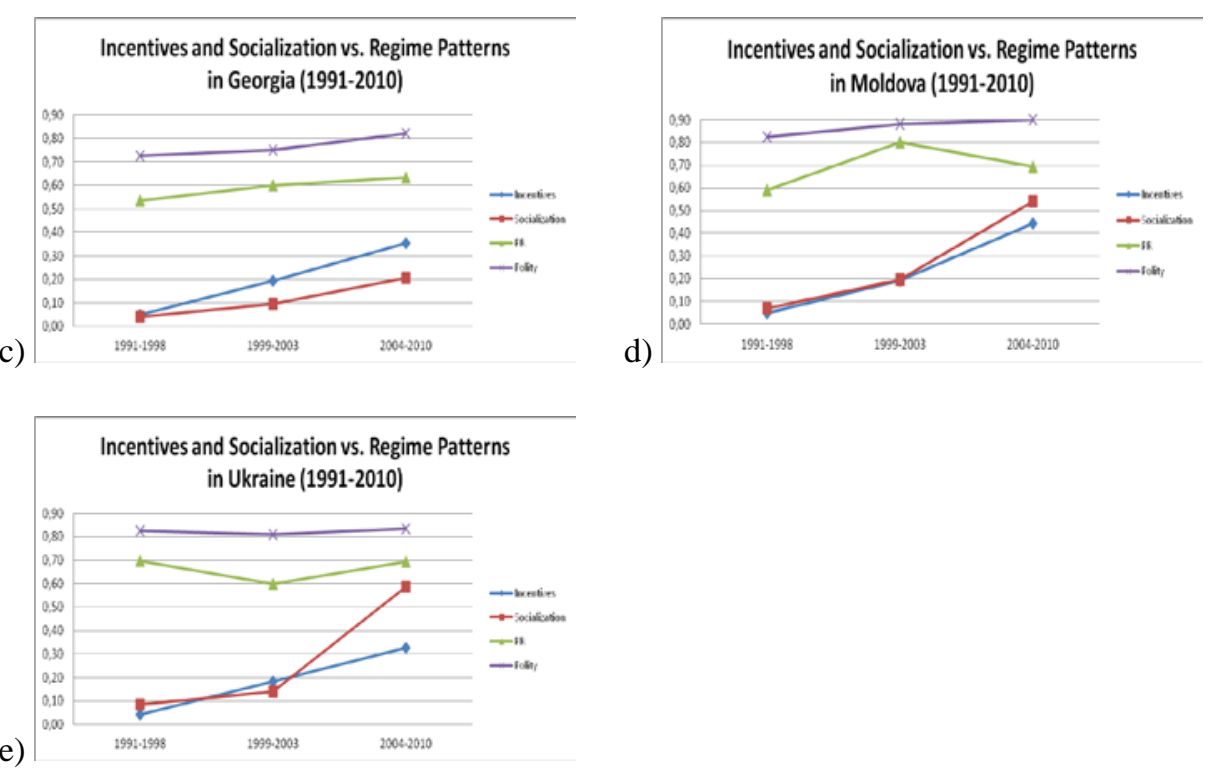

Figure $8 .^{38}$
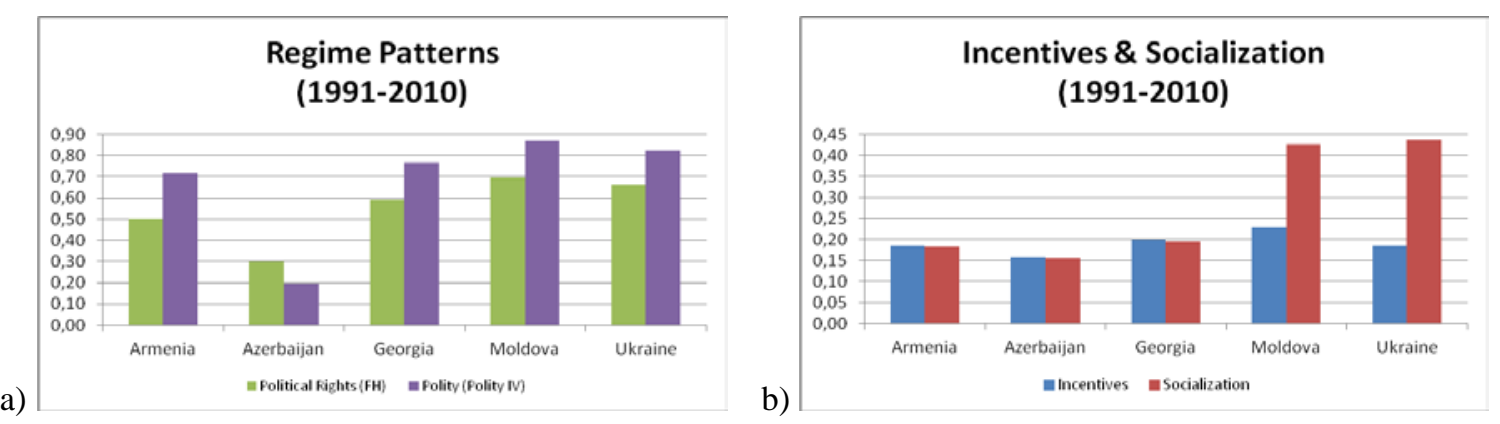

\footnotetext{
${ }^{38}$ Uses the same procedure as that referred to in fn. 37. The only difference here is that it indicates the mean values for the entire 1991-2010 period.
} 


\section{APPENDiXes}

\section{APPENDIX 1: International Instruments}

\section{CoE Instruments*}

\begin{tabular}{|c|c|c|c|c|c|c|}
\hline \multirow{30}{*}{ Human Rigths } & Title & AR & $\mathrm{AZ}$ & GE & MD & UA \\
\hline & Convention for the Protection of Human Rights and Fundamental Freedoms & s/r/f & $s / r / f$ & $s / r / f$ & s/r/f & s/r/f \\
\hline & Protocol to the Convention for the Protection of Human Rights and Fundamental Freedoms & $s / r / f$ & $\mathrm{~s} / \mathrm{r} / \mathrm{f}$ & $s / r / f$ & $\mathrm{~s} / \mathrm{r} / \mathrm{f}$ & $\mathrm{s} / \mathrm{r} / \mathrm{f}$ \\
\hline & European Social Charter & & & & & \\
\hline & Protocol No. 2 to the Convention for the Protection of Human Rights and Fundamental Freedoms, ,... & $s / r / f$ & $s / r / f$ & $s / r / f$ & $s / r / f$ & $s / r / f$ \\
\hline & Protocol No. 3 to the Convention for the Protection of Human Rights and Fundamental Freedoms, amending Articles 29,30 and 34 of the Convention & $s / r / f$ & $s / r / f$ & $s / r / f$ & s/r/f & $s / r / f$ \\
\hline & Protocol No. 4 to the Convention for the Protection of Human Rights and Fundamental Freedoms,.. & s/r/f & $s / r / f$ & $s / r / f$ & $s / r / f$ & s/r/f \\
\hline & Protocol No. 5 to the Convention for the Protection of Human Rights and Fundamental Freedoms, amending Articles 22 and 40 of the Convention & $s / r / f$ & $s / r / f$ & $s / r / f$ & $s / r / f$ & $s / r / f$ \\
\hline & European Agreement relating to Persons participating in Proceedings of the European Commission and Court of Human Rights & & & & & \\
\hline & Protocol No. 6 to the Convention for the Protection of Human Rights and Fundamental Freedoms concerning the Abolition of the Death Penalty & $s / \mathrm{r} / \mathrm{f}$ & $s / r / f$ & $s / r / f$ & $\mathrm{~s} / \mathrm{r} / \mathrm{f}$ & $\mathrm{s} / \mathrm{r} / \mathrm{f}$ \\
\hline & Protocol No. 7 to the Convention for the Protection of Human Rights and Fundamental Freedoms & $s / \mathrm{r} / \mathrm{f}$ & $\mathrm{s} / \mathrm{r} / \mathrm{f}$ & $s / r / f$ & $\mathrm{~s} / \mathrm{r} / \mathrm{f}$ & $\mathrm{s} / \mathrm{r} / \mathrm{f}$ \\
\hline & Protocol No. 8 to the Convention for the Protection of Human Rights and Fundamental Freedoms & $s / r / f$ & $s / r / f$ & $s / r / f$ & $s / r / f$ & $s / r / f$ \\
\hline & European Convention for the Prevention of Torture and Inhuman or Degrading Treatment or Punishment & $s / r / f$ & $s / r / f$ & $s / r / f$ & $s / r / f$ & $s / r / f$ \\
\hline & Additional Protocol to the European Social Charter & & & & & \\
\hline & Protocol amending the European Social Charter & & & & & \\
\hline & European Charter for Regional or Minority Languages (GE) & $s / r / f$ & s & & & $\mathrm{s} / \mathrm{R} / \mathrm{F}$ \\
\hline & Protocol No. 1 to the European Convention for the Prevention of Torture and Inhuman or Degrading Treatment or Punishment & $s / r / f$ & $\mathrm{~s} / \mathrm{r} / \mathrm{f}$ & $s / r / f$ & $\mathrm{~s} / \mathrm{r} / \mathrm{f}$ & $\mathrm{s} / \mathrm{r} / \mathrm{f}$ \\
\hline & Protocol No. 2 to the European Convention for the Prevention of Torture and Inhuman or Degrading Treatment or Punishment & $s / r / f$ & $\mathrm{~s} / \mathrm{r} / \mathrm{f}$ & $s / r / f$ & $\mathrm{~s} / \mathrm{r} / \mathrm{f}$ & $\mathrm{s} / \mathrm{r} / \mathrm{f}$ \\
\hline & Protocol No. 11 to the Convention for the Protection of Human Rights and Fundamental Freedoms, restructuring the control machinery established thereby & $s / r / f$ & $\mathrm{~s} / \mathrm{r} / \mathrm{f}$ & $s / r / f$ & $s / r / f$ & $\mathrm{~s} / \mathrm{r} / \mathrm{f}$ \\
\hline & Framework Convention for the Protection of National Minorities & $s / / / f$ & $\mathrm{a} / \mathrm{f}$ & $s / r / f$ & $s / r / f$ & $s / r / f$ \\
\hline & Additional Protocol to the European Social Charter Providing for a System of Collective Complaints & & & & & \\
\hline & European Agreement relating to persons participating in proceedings of the European Court of Human Rights & & & $s / f$ & $s / r / f$ & $s / r / f$ \\
\hline & Sixth Protocol to the General Agreement on Privileges and Immunities of the Council of Europe & $s / r / f$ & $s$ & $s / \mathrm{r} / \mathrm{f}$ & $s / r / f$ & $s / r f f$ \\
\hline & European Social Charter (revised) & $\mathrm{s} / \mathrm{r} / \mathrm{f}$ & $s / r / f$ & $s / r / f$ & $\mathrm{~s} / \mathrm{r} / \mathrm{f}$ & $\mathrm{s} / \mathrm{R} / \mathrm{F}$ \\
\hline & Protocol No. 12 to the Convention for the Protection of Human Rights and Fundamental Freedoms & $s / r / f$ & s & $s / r / f$ & & $\mathrm{~s} / \mathrm{R} / \mathrm{F}$ \\
\hline & Protocol No. 13 to the Convention for the Protection of Human Rights and Fundamental Freedoms, concerning the abolition of the death penalty in all circumstances & & & $s / r / f$ & $s / R / F$ & $\mathrm{~s} / \mathrm{r} / \mathrm{f}$ \\
\hline & Additional Protocol to the Convention on cybercrime, concerning the criminalisation of acts of a racist and xenophobic nature committed through computer systems & $s / / / F$ & & & & $S / \mathbb{R} / \mathbf{F}$ \\
\hline & Protocol No. 14 to the Convention for the Protection of Human Rights and Fundamental Freedoms, amending the control system of the Convention & $s /$ / / F & $s / r / F$ & $s / r / F$ & $s / \mathbf{R} / \mathbf{F}$ & $s / R / F$ \\
\hline & Council of Europe Convention on Action against Trafficking in Human Beings & $s / \mathbf{R} / \mathbf{F}$ & S/R/F & $s / \mathbf{R} / \mathbf{F}$ & S/R/F & $S / \mathbf{R}$ \\
\hline & Council of Europe Convention on Access to Official Documents & & & s & s & \\
\hline \multirow[t]{5}{*}{ Corruption } & Criminal Law Convention on Corruption (GE) & $s / r / f$ & $s / r / f$ & $s / \mathbf{R} / \mathbf{F}$ & $s / r / f$ & $s / \mathbb{R} / \mathbf{I}$ \\
\hline & Civil Law Convention on Corruption & s/r/f & $s / r / F$ & $s / r / f$ & $s / r / f$ & $s / R / I$ \\
\hline & Additional Protocol to the Criminal Law Convention on Corruption & $s / r / f$ & & & $\mathrm{~s} / \mathrm{R} / \mathrm{F}$ & $s / R / 1$ \\
\hline & Total (Instruments) & 2 & & 19 & 23 & 23 \\
\hline & Total (Actions following the ENPAPS) & & & 2 & 3 & \\
\hline
\end{tabular}

*Status as of end 2010

Source: http://conventions.coe.int/Treaty/EN/v3MenuTraites.asp

Legend: s: signature

r: ratification

a: accession (=ratification)

f: entry into force

s/f: signature without reservation as to ratification

UPPER CASE \& Bold: actions follow after the launch of the ENPAPs 


\section{UN Instruments*}

\begin{tabular}{|c|c|c|c|c|c|c|}
\hline Field & Title & AM & AZ & GE & MD & UA \\
\hline \multirow[t]{25}{*}{ Human Rights } & 5 Convention on the Prevention and Punishment of the Crime of Genocide (09.12.48) & a & a & a & s, & $s / r$ \\
\hline & International Convention on the Elimination of All Forms of Racial Discrimination (07.03.66) & a & a & a & a & $s / r$ \\
\hline & Amendment to article 8 of the International Convention on the Elimination of All Forms of Racial Discrimination (15.01.92) & : & : & : & a & ac \\
\hline & International Covenant on Economic, Social and Cultural Rights (16.12.66) & a & a & a & a & $s / r$ \\
\hline & Optional Protocol to the International Covenant on Economic, Social and Cultural Rights (10.12.08) & $\mathbf{s}$ & $\mathbf{S}$ & : & $\mathbf{S}$ & $\mathbf{s}$ \\
\hline & International Covenant on Civil and Political Rights (16.12.66) & a & a & a & a & $s / r$ \\
\hline & Optional Protocol to the International Covenant on Civil and Political Rights (16.12.66) & a & a & a & $\mathbf{S} / \mathbf{R}$ & a \\
\hline & Convention on the non-applicability of statutory limitations to war crimes and crimes against humanity (26.11.68) & a & a & a & a & $s / r$ \\
\hline & International Convention on the Suppression and Punishment of the Crime of Apartheid (30.11.73) & a & a & a & a & $s / r$ \\
\hline & Convention on the Elimination of All Forms of Discrimination against Women (18.12.79) & a & a & a & a & $s / r$ \\
\hline & Amendment to article 20, paragraph 1 of the Convention on the Elimination of All Forms of Discrimination against Women (22.12.95) & : & AC & ac & & \\
\hline & Optional Protocol to the Convention on the Elimination of All Forms of Discrimination against Women (06.10.99) & a & $s / r$ & a & A & $s / r$ \\
\hline & Convention against Torture and Other Cruel, Inhuman or Degrading Treatment or Punishment (10.12.84) & a & a & a & a & $s / r$ \\
\hline & Amendments to articles 17 (7) and 18 (5) of the Convention against Torture and Other Cruel, Inhuman or Degrading Treatment or Punishment (08.09.92) & : & $:$ & $:$ & & ac \\
\hline & Optional Protocol to the Convention against Torture and Other Cruel, Inhuman or Degrading Treatment or Punishment (18.12.02) & a & $s / \mathbf{R}$ & a & $S / R$ & S/R \\
\hline & International Convention against Apartheid in Sports (10.12.85) & & : & & & $s / r$ \\
\hline & Convention on the Rights of the Child (20.11.89) & a & a & a & a & $s / r$ \\
\hline & Amendment to article 43 (2) of the Convention on the Rights of the Child (12.12.95) & & $:$ & ac & ac & ac \\
\hline & Optional Protocol to the Convention on the Rights of the Child on the involvement of children in armed conflict (25.05.00) & $s / r$ & $s / r$ & A & $s / r$ & $s / \mathbf{R}$ \\
\hline & Optional Protocol to the Convention on the Rights of the Child on the sale of children, child prostitution and child pornography (25.05.00) & $s / r$ & $s / r$ & a & $s / \mathbf{R}$ & $s / r$ \\
\hline & Second Optional Protocol to the International Covenant on Civil and Political Rights, aiming at the abolition of the death penalty (15.12.89) & a & a & a & A & A \\
\hline & International Convention on the Protection of the Rights of All Migrant Workers and Members of their Families (18.12.90) & & a & & & \\
\hline & Convention on the Rights of Persons with Disabilities (13.12.06) & $S / R$ & $S / R$ & s & S/R & S/R \\
\hline & Optional Protocol to the Convention on the Rights of Persons with Disabilities (13.12.06) & $\mathbf{s}$ & $S / R$ & s & & $S / R$ \\
\hline & International Convention for the Protection of All Persons from Enforced Disappearance (20.12.06) & $\mathbf{s}$ & $\mathbf{s}$ & s & $\mathbf{s}$ & \\
\hline \multirow[t]{3}{*}{ Corruption } & United Nations Convention against Corruption & $s / \mathbf{R}$ & $s / r$ & A & $s / \mathbf{R}$ & $s / R$ \\
\hline & Total (Instruments) & 16 & 20 & 18 & 18 & 22 \\
\hline & Total (Actions following the ENPAPS) & 6 & 8 & 4 & 11 & 10 \\
\hline
\end{tabular}

*Status as of end 2010

Source: http://treaties.un.org/Pages/DB.aspx?path=DB/MTDSG/page1_en.xml\&menu=MTDSG

Legend: a: accession (=acceptance, ratification [not at national level])

ac: acceptance

1. ratification

UPPER CASE \& Bold: actions follow after the launch of the ENPAPs

Italics: instruments not entered yet into force 
APPENDIX 2: Dependent Variable and Indicators ${ }^{39}$

Dependent Variable:

\begin{tabular}{|c|c|c|c|c|c|}
\hline Variable & Description & Transformation & \multicolumn{2}{|c|}{ Calibration } & Source \\
\hline $\begin{array}{l}\text { Political } \\
\text { Rights } \\
\text { (PRs) }\end{array}$ & $\begin{array}{l}\text { PRs refer to three } \\
\text { dimensions: Electoral } \\
\text { process; Political } \\
\text { pluralism and } \\
\text { participation; } \\
\text { Functioning of } \\
\text { government }^{40}\end{array}$ & $\begin{array}{l}\text { The original } \\
\text { continuous scale from } \\
1 \text { (wide range of PRs) } \\
\text { to } 7 \text { (few or no PRs) is } \\
\text { inversed so that higher } \\
\text { ratings refer to higher } \\
\text { standards of PRs. }\end{array}$ & $\begin{array}{l}7 \text { (theoretical } \\
\text { maximum) }\end{array}$ & $1,00^{41}$ & $\begin{array}{l}\text { Freedom } \\
\text { House }\end{array}$ \\
\hline Polity & $\begin{array}{l}\text { The Polity score is an } \\
\text { account of both } \\
\text { democracy and } \\
\text { autocracy scores }\end{array}$ & $\begin{array}{l}\text { The original } \\
\text { continuous scale from } \\
-10 \text { (strongly } \\
\text { autocratic) to }+10 \\
\text { (strongly democratic) } \\
\text { is transformed into a } \\
\text { scale from } 0 \text { (strongly } \\
\text { autocratic) to } 20 \\
\text { (strongly democratic). }\end{array}$ & $\begin{array}{l}20 \text { (theoretical } \\
\text { maximum) }\end{array}$ & $1,00^{43}$ & Polity IV \\
\hline
\end{tabular}

\section{Conditionality:}

\begin{tabular}{|c|c|c|c|c|c|}
\hline Indicator & Description & Scoring & \multicolumn{2}{|c|}{ Calibration } & Source \\
\hline $\begin{array}{c}\text { Bilateral } \\
\text { agreement }\end{array}$ & $\begin{array}{l}\text { The type of agreement } \\
\text { regulating the EU } \\
\text { relations with a target } \\
\text { country }\end{array}$ & $\begin{array}{l}\text { The more advanced } \\
\text { this agreement, the } \\
\text { higher the perceived } \\
\text { credibility of rewards }\end{array}$ & $\begin{array}{l}\text { No agreement } \\
\text { PCA } \\
\text { ENPAP }\end{array}$ & $\begin{array}{l}0,00 \\
0,25 \\
0,50^{44}\end{array}$ & Author \\
\hline $\begin{array}{c}\text { EU } \\
\text { assistance } \\
\text { per capita }\end{array}$ & $\begin{array}{l}\text { Annual assistance per } \\
\text { capita provided by the } \\
\text { EU }\end{array}$ & $\begin{array}{l}\text { The larger the volume } \\
\text { (size) of assistance, the } \\
\text { higher the perceived } \\
\text { reward }\end{array}$ & $\begin{array}{l}29.11 € / \text { cap } \\
\text { (empirical } \\
\text { maximum, MD, } \\
2010 \text { ) }\end{array}$ & $1,00^{45}$ & $\begin{array}{l}\text { European } \\
\text { Commission }\end{array}$ \\
\hline $\begin{array}{l}\text { Commercial } \\
\text { regime }\end{array}$ & $\begin{array}{l}\text { The type of commercial } \\
\text { regime between the EU } \\
\text { and a target country }\end{array}$ & $\begin{array}{l}\text { The more advanced } \\
\text { this regime, the higher } \\
\text { the perceived reward }\end{array}$ & $\begin{array}{l}\text { No preferences } \\
\text { GSPind }{ }^{46} \\
\text { GSP } \\
\text { GSP+ } \\
\text { ATP }\end{array}$ & $\begin{array}{l}0,00 \\
0,10 \\
0,25 \\
0,50 \\
0,75^{47}\end{array}$ & Author \\
\hline
\end{tabular}

\footnotetext{
${ }^{39}$ Data is available from the author upon request.

${ }^{40}$ For more information see Freedom House, Freedom in the World, http://www. freedomhouse.org.

${ }^{41}$ Calibrated values are arrived at after dividing a particular score to the theoretical maximum.

42 For more details on democracy and autocracy scores see Marshall, M.G. and Jaggers, K., Polity IV Project: Political Regime Characteristics and Transitions, 1800-2010, http://www.systemicpeace.org/polity/polity4.htm.

${ }^{43}$ The procedure is similar to that referred to in fn. 41 .

44 The next generation of agreements between the EU and ENPC would increase the credibility of rewards $(0,75)$, but it will still fall short of that $(1,00)$ entailed by bilateral agreements providing for a membership perspective.

${ }^{45}$ Other country-year values are deduced dividing a particular amount of EU assistance per capita provided to a given country in a given year to the empirical maximum in the sample.

${ }^{46}$ GSP in respect to certain industrial products.

${ }^{47}$ FTA would get a 1,00 value.
} 


\begin{tabular}{|l|l|l|l|l|l|}
\hline Visa regime & $\begin{array}{l}\text { The type of visa regime } \\
\text { between the EU and a } \\
\text { target country }\end{array}$ & $\begin{array}{l}\text { The more advanced } \\
\text { this regime, the higher } \\
\text { the perceived reward }\end{array}$ & $\begin{array}{l}\text { Not free } \\
\text { Facilitated }\end{array}$ & $\begin{array}{l}0,00 ; \\
0,50^{48}\end{array}$ & Author \\
\hline
\end{tabular}

\section{Socialization:}

\begin{tabular}{|c|c|c|c|c|c|}
\hline Indicator & Description & Scoring & \multicolumn{2}{|c|}{ Calibration } & Source \\
\hline $\begin{array}{c}\text { EU } \\
\text { programs }\end{array}$ & $\begin{array}{l}\text { Instances of } \\
\text { participation/ } \\
\text { membership in EU } \\
\text { programs }\end{array}$ & $\begin{array}{l}\text { The higher the number } \\
\text { of these instances, the } \\
\text { higher the score }\end{array}$ & $\begin{array}{l}\text { Membership in } \\
\text { each EU } \\
\text { program }\end{array}$ & 0,10 & Author \\
\hline $\begin{array}{c}\text { Taiex, } \\
\text { Twinning }\end{array}$ & $\begin{array}{l}\text { Instances of } \\
\text { participation in Taiex } \\
\text { events and Twinning } \\
\text { projects }\end{array}$ & $\begin{array}{l}\text { The higher the number } \\
\text { of these instances, the } \\
\text { higher the score }\end{array}$ & $\begin{array}{l}160 \text { (empirical } \\
\text { maximum, UA, } \\
\text { 2005-2010) }\end{array}$ & $1,00^{49}$ & $\begin{array}{l}\text { European } \\
\text { Commission, } \\
\text { author }\end{array}$ \\
\hline $\begin{array}{c}\text { Europ. reg. } \\
\text { org. }\end{array}$ & $\begin{array}{l}\text { Instances of membership } \\
\text { in European reg. org. } \\
\text { where the EU member } \\
\text { states represent a } \\
\text { significant share }\end{array}$ & $\begin{array}{l}\text { As number of such } \\
\text { instances multiplied } \\
\text { by their cumulate } \\
\text { duration. }{ }^{50} \text { The higher } \\
\text { the product, the higher } \\
\text { the score }\end{array}$ & $\begin{array}{l}240 \text { (empirical } \\
\text { maximum, MD, } \\
2010 \text { ) }\end{array}$ & $1,00^{51}$ & Author \\
\hline $\begin{array}{c}\text { Trade with } \\
\text { EU }\end{array}$ & $\begin{array}{l}\text { EU annual share in the } \\
\text { total trade }^{52}\end{array}$ & $\begin{array}{l}\text { The higher the share, } \\
\text { the higher the score }\end{array}$ & $\mathrm{x} \% / 100$ & & DOTS (IMF) \\
\hline $\begin{array}{l}\text { Proximity } \\
\text { to EU }\end{array}$ & $\begin{array}{l}\text { Geographical distance } \\
\text { between the EU and a } \\
\text { target country }\end{array}$ & $\begin{array}{l}\text { As direct / non-direct } \\
\text { land neighbour of the } \\
\text { EU }\end{array}$ & $\begin{array}{l}\text { Non-direct land } \\
\text { neighbour } \\
\text { Direct land } \\
\text { neighbour }\end{array}$ & $\begin{array}{l}0,00 \\
1,00\end{array}$ & Author \\
\hline
\end{tabular}

\footnotetext{
${ }^{48}$ A free visa regime would get a 1,00 value.

${ }^{49}$ Used to deduce values for other countries. The procedure is similar to that referred to in fn. 45. calculate values for the preceding years and all other cases.

${ }^{51}$ Used to deduce values for other country-years. The procedure is similar to that referred to in fn. 45.

${ }^{52}$ Average of imports from and exports to EU of a given country in a given year.
}

${ }^{50}$ It approximates the extent to which target countries were "entrapped” into a socialization dynamics in regional groupings where the EU Member States have an important role to play. Armenia, Azerbaijan, Georgia are members of CoE and OSCE, Moldova is a member of CoE, OSCE, CEI and RCC, and Ukraine is a member of CoE, OSCE and CEI. Example: in 2010 the duration of Armenia's membership in the OSCE was 19 years, whereas that of its presence in the CoE was 10 years. The resulting cumulative sum $29(=10+19)$ is then multiplied with 2, the number of membership instances of Armenia in such European regional organisations $(29 * 2=58)$. The same procedure is used to 


\section{REFERENCES}

Boonstra, J. and Shapovalova, N. (2010), The EU’s Eastern Partnership: One Year Backwards, Internet web site for the FRIDE, accessed September $16^{\text {th }} 2010$, http://www.fride. org/publication/764/the-eu\%27-seastern-partnership:-one-year-backwards.

Börzel, T.A. (2010), The Transformative Power of Europe Reloaded. The Limits of External Europeanization, Internet web site for the Department of Political and Social Sciences, Free University Berlin, accessed 28th August 2010, http://www.polsoz.fu-berlin.de/en/index.html.

Börzel, T.A. and Risse, T. (2009), The Transformative Power of Europe. The European Union and the Diffusion of Ideas, Internet web site for the Department of Political and Social Sciences, Free University Berlin, accessed 15th February 2010, http://www.polsoz.fu-berlin.de/en/index.html.

Casier, T. (2009), The Two-Track Approach to Democracy Promotion in the European Neighbourhood Policy, Paper presented at the EUSA conference in Los Angeles, April 2009.

Checkel, J.T. (2005), “International Institutions and Socialization in Europe: Introduction and Framework”, International Organization, 59, pp. 801-826.

Council of the EU (2003), A Secure Europe in a Better World - European Security Strategy, Internet web site for the Council of the EU, accessed 14th April 2011, http://www.consilium.europa.eu/uedocs/ cmsUpload/78367.pdf.

Council of the EU (2006), The EU Approach To Democracy Promotion in External Relations. Food For Thought, Internet web site for the Institute of Multiparty Democracy, accessed 28th March 2011, http://www.democracyteam.org/modules.php?mop=modload\&name=Upload\&file=index\&op=show\&mid=2.

Council of the EU (2009), Joint Declaration of the Prague Eastern Partnership Summit, 8435/09 (Presse 78), Internet web site for the Council of the EU, accessed 14th July 2011, http://www.consilium.europa.eu/ uedocs/cms_data/docs/pressdata/en/er/107589.pdf.

Epstein, R.A. and Sedelmeier, U. (2008), "Beyond Conditionality: International Institutions in Postcommunist Europe after Enlargement“, Journal of European Public Policy, 15(6), pp. 795-805.

EU-Armenia/Azerbaijan/Georgia/Moldova/Ukraine Action Plan, Internet web site for the European Commission, accessed 5th October 2010, http://ec.europa.eu/world/enp/documents_en.htm\#2. 
European Commission (2000a), Follow-up to the First Summit between Latin America, the Caribbean and the European Union, $\operatorname{COM(2000)} 670$ final, Internet web site for the European Union, accessed 5th April 2011, http://eur-lex.europa.eu/en/index.htm.

European Commission (2000b), To Prepare the Forth Meeting of Euro-Mediterranean Foreign Ministers: "Reinvigorating the Barcelona Process”, $\operatorname{COM(2000)} 497$ final, Internet web site for the European Union, accessed 5th April 2011, http://eur-lex.europa.eu/en/ index.htm.

European Commission (2001), The European Union's Role in Promoting Human Rights and Democratization in Third Countries, COM(2001) 252 final, Internet web site for the European Union, accessed 7th April 2011, http://eur-lex.europa.eu/en/index.htm.

European Commission (2003a), Wider Europe - Neighbourhood: A New Framework for Relations with our Eastern and Southern Neighbours, COM(2003) 104 final, Internet web site for the European Commission, accessed 17th October 2010, http://ec.europa.eu/world/enp/pdf/ com03_104_en.pdf.

European Commission (2003b), Paving the Way for a New Neighbourhood Instrument, COM(2003) 393 final, Internet web site for the European Commission, accessed 17th October 2010, http://ec.europa.eu/comm/world/enp/pdf/com03_393_en.pdf.

European Commission (2004), European Neighbourhood Policy Strategy Paper, COM(2004) 373 final, Internet web site for the European Commission, accessed 17th October 2010, http://ec.europa.eu/world/enp/pdf/ strategy/strategy_paper_en.pdf.

European Commission (2005), Implementing and Promoting the European Neighbourhood Policy, SEC(2005) 1521, Internet web site for the European Commission, accessed 27th December 2010, http://ec.europa.eu/world/enp/documents_en.htm.

European Commission (2006a), Strengthening the European Neighbourhood Policy, COM(2006) 726 final, Internet web site for the European Commission, accessed 17th October 2010, http://ec.europa.eu/world/ enp/documents_en.htm\#1.

European Commission (2006b), Thematic Programme for the Promotion of Democracy and Human Rights Worldwide under the Future Financial Perspectives (2007-2013), COM(2006) 23 final, Internet web site for the European Union, accessed 8th April 2011, http://eur-lex.europa.eu/en/index.htm.

European Commission (2006c-g), Armenia/Azerbaijan/Georgia/Moldova/Ukraine. National Indicative Programme 2007-2013, Internet web site for the European Commission, accessed 2nd April 2011, http://ec.europa.eu/world/enp/index_en.htm. 
European Commission (2006h), Communication on the General Approach to Enable ENP Partner Countries to Participate in Community Agencies and Community Programmes, COM(2006) 724 final, Internet web site for the European Commission, accessed 18th October 2010, http://ec.europa.eu/world/enp/documents_ en.htm\#4.

European Commission (2007), A Strong European Neighbourhood Policy, COM(2007) 774 final, Internet web site for the European Commission, accessed 17th October 2010, http://ec.europa.eu/world/enp/ documents_en.htm\#1.

European Commission (2008), Eastern Partnership, COM(2008) 823 final, Internet web site for the European Commission, accessed 17th July 2011, http://eeas.europa.eu/eastern/docs/com08_823_en.pdf.

European Commission (2011a), A New Response to a Changing Neighbourhood, COM(2011) 303, Internet web site for the European Commission, accessed 17th July 2011, http://ec.europa.eu/world/enp/pdf/ com_11_303_en.pdf.

European Commission (2011b), Implementation of the European Neighbourhood Policy in 2010. Report: Eastern Partnership, SEC(2011) 641, Internet web site for the European Commission, accessed 17th July 2011, http://ec.europa.eu/world/enp/pdf/progress2011/sec_11_641_en.pdf.

European Commission (2011c), Implementation of the European Neighbourhood Policy in 2010. Follow-Up to the Joint Communication on a Partnership for Democracy and Shared Prosperity with the Southern Mediterranean, SEC(2011) 638, Internet web site for the European Commission, accessed 17th July 2011, http://ec.europa.eu/world/enp/pdf/progress2011/sec_11_638_en.pdf.

European Council (1991), Conclusions of the Presidency, Internet web site for the European Parliament, accessed 6th April 2011, http://www.europarl.europa.eu/summits/luxembourg/default_en.htm.

European Council (1993), Conclusions of the Presidency, Internet web site for the Council of the European Union, accessed 6th April 2011, http://ue.eu.int/ueDocs/cms_Data/docs/pressData/en/ec/72921.pdf.

Finnemore, M. and Sikkink, K. (1998), “International Norm Dynamics and Political Change”, International Organization, 52(4), pp. 887-917.

Freyburg, T. (2009), Democrats without Democracy? Linkage and Socialization into Democratic Governance in Authoritarian Regimes, Internet web site for the National Centre of Competence in Research, accessed 15th August 2010, http://www.nccr-democracy.uzh.ch.

Freyburg, T., Lavenex, S., Schimmelfennig, F., Skripka, T. and Wetzel, A. (2009), "EU Promotion of Democratic Governance in the Neighbourhood”, Journal of European Public Policy, 16(6), pp. 916-934. 
Goertz, G. (2005), Social Science Concepts: A User's Guide, Princeton, Princeton University Press.

Gordon, C. and Sasse, G. (2008), The European Neighbourhood Policy: Effective Instrument for Conflict Management and Democratic Change in the Union’s Eastern Neighbourhood?, Internet web site for the EURAC, accessed 27th August 2010, http://www.eurac.edu/en/research/institutes/imr/Documents/Web_ del29ENP.pdf.

Kelley, J. (2004), "International Actors on the Domestic Scene: Membership Conditionality and Socialization by International Institutions”, International Organization, 58, pp. 425-457.

Kochenov, D. (2008), “The ENP Conditionality: Pre-accession Mistakes Repeated”, in Delcour, L. and Tulmets, L. (eds.), Pioneer Europe? Testing EU Foreign Policy in the Neighbourhood, Baden Baden, Nomos.

Kochenov, D. (2009), The Eastern Partnership, the Union for the Mediterranean and the Remaining Need to Do Something with the ENP, CRCEES Working Papers WP2009/01, Internet web site for the Social Science Research Network, accessed 27th August 2010, http://papers.ssrn.com/sol3/papers.cfm?abstract_id= 1459560.

Kubicek, P.J. (ed.) (2003), The European Union and Democratization, London, Routledge.

Lavenex, S. (2004), “EU External Governance in Wider Europe”, Journal of European Public Policy, 11(4), pp. 680-700.

Lavenex, S. (2008), “A Governance Perspective on the European Neighbourhood Policy: Integration Beyond Conditionality?”, Journal of European Public Policy, 15(6), pp. 938-955.

Lavenex, S. and Schimmelfennig, F. (2007), "Relations with the Wider Europe”, Journal of Common Market Studies, 45, pp. 143-162.

Lavenex, S. and Schimmelfennig, F. (2009), "EU Rules Beyond EU Borders: Theorizing External Governance in European Politics“, Journal of European Public Policy, 16(6), pp. 791-812.

Levitsky, S. and Way, L.A. (2005), “International Linkage and Democratization”, Journal of Democracy, 16(3), pp. 21-34.

Levitsky, S. and Way, L.A. (2010), Competitive Authoritarianism: Hybrid Regimes after the Cold War, Cambridge, Cambridge University Press.

Magen, A. (2006), “The Shadow of Enlargement: Can the European Neighbourhood Policy Achieve Compliance?”, The Columbia Journal of European Law, 12(2), pp. 383-427. 
March, J.G. and Olsen, J.P. (2004), The Logic of Appropriateness, ARENA Working Papers no.04/09, Internet web site for the Centre for European Studies, University of Oslo, accessed 17th February 2010, http://www.arena.uio.no.

Menkiszak, M., Konończuk, W. and Kaczmarski, M. (2008), CIS Countries’ Interests vis-à-vis the European Union and Its Eastern Policy, CASE Network Studies and Analyses No.365/2008, Internet web site for the CASE, accessed 11th September 2010, http://www.case.com.pl/upload/publikacja_plik/21136746_sa365.pdf.

Mungiu-Pippidi, A. (2005), "EU Enlargement and Democracy Progress”, in Emerson, M. (ed.), Democratisation in the European Neighbourhood, Brussels, CEPS, pp. 15-37.

Nikolov, K. (2007), The Eastern EU Neighbourhood: How to Enhance the EU’s Partners' Ownership of the ENP, Internet web site for the TEPSA, accessed 14th September 2010, http://www.tepsa.eu/docs/ ownership_of_enp.pdf.

O’Loughlin, J., Ward, M.D., Lofdahl, C.L., Cohen, J.S., Brown, D.S., Reilly, D., Gleditsch, K.S. and Shin, M. (1998), “The Diffusion of Democracy, 1946-1994”, Annals of the Association of American Geographers, 88 (4), pp. 545-574.

Patten, Ch. (2004), “Islam and the West - At the Crossroads”, Speech no. 86/04, Internet web site for the Oxford Centre for Islamic Studies, University of Oxford, accessed 21st June 2010, www.oxcis.ac.uk/lectures/ Patten.doc.

Progress Reports: Overall Assessment (2006, 2008, 2009, 2010, 2011); Sectoral (2006, 2008, 2009, 2010, 2011); Armenia (2008, 2009, 2010, 2011), Azerbaijan (2008, 2009, 2010, 2011), Georgia (2008, 2009, 2010, 2011), Moldova (2006, 2008, 2009, 2010, 2011), Ukraine (2006, 2008, 2009, 2010, 2011), Internet web site for the European Commission, accessed 10th January 2011, http://ec.europa.eu/world/enp/documents_ en.htm\#3.

Ragin, Ch.C. (2008), Redesigning Social Inquiry: Fuzzy Sets and Beyond, Chicago, University of Chicago Press.

Sasse, G. (2008), The ENP Process and the EU's Eastern Neighbours: 'Conditionality-lite', Socialisation and 'Procedural Entrapment', Global Europe Papers 2008/9, Internet web site for the University of Bath, accessed 15th September 2010, http://www.bath.ac.uk/esml/research/security/pdf/sasse.pdf.

Schimmelfennig, F. (2005), The International Promotion of Political Norms in Eastern Europe: A Qualitative Comparative Analysis, Jean Monnet/ Robert Schuman Paper Series no.5(28), Internet web site for 
the Miami European Union Center, University of Miami, accessed 27th December 2009, http://www6.miami. edu/eucenter.

Schimmelfennig, F. (2007), “European Regional Organizations, Political Conditionality, and Democratic Transformation in Eastern Europe”, East European Politics and Societies, 21(1), pp. 126-141.

Schimmelfennig, F. and Scholz, H. (2008), "EU Democracy Promotion in the European Neighbourhood: Political Conditionality, Economic Development and Transnational Exchange”, European Union Politics, 9(2), pp. 187-215.

Schimmelfennig, F. and Scholtz, H. (2010), “Legacies and Leverage. EU Political Conditionality and Democracy Promotion in Historical Perspective”, Europe-Asia Studies, 62(3), pp. 443-460.

Short, R. et al. (2006), Evaluation of Council Regulation 99/2000 (TACIS) and Its Implementation Ref. 728, Internet web site for the European Commission, accessed 25th March 2011, http://ec.europa.eu/ europeaid/how/evaluation/evaluation_reports/2006/728_docs_en.htm.

Smith, K.E. (1997), The Use of Political Conditionality in the EU's Relations with Third Countries: How Effective?, Paper for the ECSA International Conference, Seattle, 29 May - 1 June 1997.

Stahn, A. and van Hüllen, V. (2007), Different Actors, Different Tools? Approaching EU and US Democracy Promotion in the Mediterranean and the Newly Independent States, Paper prepared for the EUSA Tenth Biennial International Conference, May 17-19 2007, Montreal, Canada.

Vachudova, M.A. (2006), Democratization in Postcommunist Europe: Illiberal Regimes and the Leverage of International Actors, CES Working Paper Series no.139, Internet web site for the Center for European Studies, Harvard University, accessed 15th November 2009, http://www.ces.fas.harvard.edu/index. html.

Youngs, R. (2008), “Trends in Democracy Assistance: What Has Europe Being Doing”, Journal of Democracy, 19(2), pp. 160-169.

Youngs, R. (2009), “Democracy Promotion as External Governance?”, Journal of European Public Policy, 16(6), pp. 895-915.

Zürn, M. and Checkel, J.T. (2005), “Getting Socialized to Build Bridges: Constructivism and Rationalism, Europe and the Nation-State”, International Organization, 59, pp. 1045-1079. 